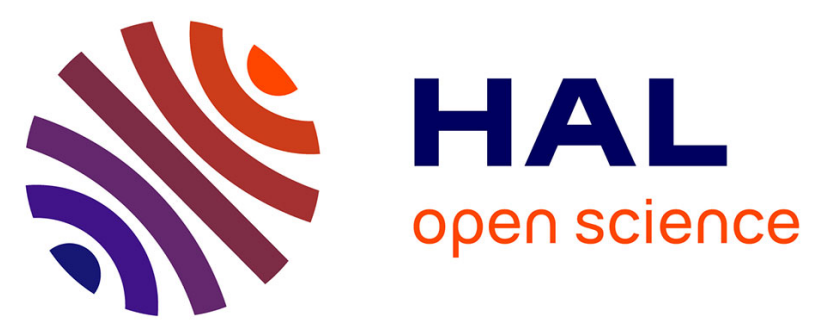

\title{
The Catastrophic Flash-Flood Event of 8-9 September 2002 in the Gard Region, France: A First Case Study for the Cévennes-Vivarais Mediterranean Hydrometeorological Observatory
}

G. Delrieu, John Nicol, E. Yates, P.E. Kirstetter, J.D. Creutin, S. Anquetin, C. Obled, Georges-Marie Saulnier, Vincent Ducrocq, E. Gaume, et al.

\section{To cite this version:}

G. Delrieu, John Nicol, E. Yates, P.E. Kirstetter, J.D. Creutin, et al.. The Catastrophic Flash-Flood Event of 8-9 September 2002 in the Gard Region, France: A First Case Study for the CévennesVivarais Mediterranean Hydrometeorological Observatory. Journal of Hydrometeorology, 2005, 6 (1), pp.34-52. 10.1175/JHM-400.1 . insu-00271531

\section{HAL Id: insu-00271531}

https://hal-insu.archives-ouvertes.fr/insu-00271531

Submitted on 10 Mar 2021

HAL is a multi-disciplinary open access archive for the deposit and dissemination of scientific research documents, whether they are published or not. The documents may come from teaching and research institutions in France or abroad, or from public or private research centers.
L'archive ouverte pluridisciplinaire HAL, est destinée au dépôt et à la diffusion de documents scientifiques de niveau recherche, publiés ou non, émanant des établissements d'enseignement et de recherche français ou étrangers, des laboratoires publics ou privés. 


\title{
The Catastrophic Flash-Flood Event of 8-9 September 2002 in the Gard Region, France: A First Case Study for the Cévennes-Vivarais Mediterranean Hydrometeorological Observatory
}

\author{
Guy Delrieu, ${ }^{a}$ Véronique Ducroce, ${ }^{\mathrm{b}}$ Eric Gaume, ${ }^{\mathrm{c}}$ John Nicol, ${ }^{\mathrm{a}}$ Olivier Payrastre, ${ }^{\mathrm{c}}$ \\ Eddy Yates, ${ }^{a}$ Pierre-Emmanuel Kirstetter, ${ }^{a}$ Hervé Andrieu, ${ }^{\mathrm{d}}$ Pierre-Alain Ayral, ${ }^{\mathrm{e}}$ \\ Christophe Bouvier, ${ }^{\mathrm{f}}$ JeAn-Dominique Creutin, ${ }^{\mathrm{a}}$ MArc Livet,${ }^{\mathrm{g}}$ Sandrine Anquetin, ${ }^{\mathrm{a}}$ \\ Michel Lang, ${ }^{\text {h }}$ Luc Neppel, ${ }^{f}$ Charles Obled, ${ }^{a}$ JacQues Parent-Du-Châtelet, ${ }^{\text {i }}$ \\ Georges-Marie Saulnier, ${ }^{\mathrm{a}}$ Andrea Walpersdorf, ${ }^{\mathrm{j}}$ And Wolfram Wobrock ${ }^{\mathrm{k}}$ \\ a Laboratoire d'Étude des Transferts en Hydrologie et Environnement, Grenoble, France \\ ${ }^{\mathrm{b}}$ Centre National de Recherche Météorologique, CNRM/GAME, Toulouse, France \\ ${ }^{\mathrm{c}}$ Centre d'Enseignement et de Recherche Eau Ville Environnement, Marne-la-Vallée, France \\ ${ }^{\mathrm{d}}$ Laboratoire Central des Ponts et Chaussées, Division Eau, Bouguenais, France \\ e Ecole des Mines d'Alès, Alès, France \\ ${ }^{\mathrm{f}} H y d r o s c i e n c e s-M a i s o n$ des Sciences de l'Eau, Montpellier, France \\ ${ }^{\mathrm{g}}$ Laboratoire Régional des Ponts et Chaussées, Clermont-Ferrand, France \\ ${ }^{\mathrm{h}}$ Institut de Recherche pour l'Ingénierie de l'Agriculture et de l'Environnement, CEMAGREF, \\ Groupement de Lyon, Lyon, France \\ ${ }^{\mathrm{i}}$ Centre de Météorologie Radar, Météo-France, Trappes, France \\ ${ }^{\mathrm{j}}$ Laboratoire de Géophysique Interne et de Tectonophysique, Grenoble, France \\ ${ }^{\mathrm{k}}$ Laboratoire de Météorologie Physique, Aubière, France
}

(Manuscript received 12 February 2004, in final form 9 July 2004)

\section{ABSTRACT}

The Cévennes-Vivarais Mediterranean Hydrometeorological Observatory (OHM-CV) is a research initiative aimed at improving the understanding and modeling of the Mediterranean intense rain events that frequently result in devastating flash floods in southern France. A primary objective is to bring together the skills of meteorologists and hydrologists, modelers and instrumentalists, researchers and practitioners, to cope with these rather unpredictable events. In line with previously published flash-flood monographs, the present paper aims at documenting the 8-9 September 2002 catastrophic event, which resulted in 24 casualties and an economic damage evaluated at 1.2 billion euros (i.e., about 1 billion U.S. dollars) in the Gard region, France. A description of the synoptic meteorological situation is first given and shows that no particular precursor indicated the imminence of such an extreme event. Then, radar and rain gauge analyses are used to assess the magnitude of the rain event, which was particularly remarkable for its spatial extent with rain amounts greater than $200 \mathrm{~mm}$ in $24 \mathrm{~h}$ over $5500 \mathrm{~km}^{2}$. The maximum values of $600-700 \mathrm{~mm}$ observed locally are among the highest daily records in the region. The preliminary results of the postevent hydrological investigation show that the hydrologic response of the upstream watersheds of the Gard and Vidourle Rivers is consistent with the marked space-time structure of the rain event. It is noteworthy that peak specific discharges were very high over most of the affected areas $\left(5-10 \mathrm{~m}^{3} \mathrm{~s}^{-1} \mathrm{~km}^{-2}\right)$ and reached locally extraordinary values of more than $20 \mathrm{~m}^{3} \mathrm{~s}^{-1} \mathrm{~km}^{-2}$. A preliminary analysis indicates contrasting hydrological behaviors that seem to be related to geomorphological factors, notably the influence of karst in part of the region. An overview of the ongoing meteorological and hydrological research projects devoted to this case study within the OHM-CV is finally presented.

\section{Introduction}

On 8-9 September 2002, a major mesoscale convective system (MCS) affected the Gard area in the Cévennes-Vivarais region, France: 24 people were killed dur-

Corresponding author address: Dr. Guy Delrieu, LTHE, UMR 5564 (CNRS, UJF, INPG, IRD), BP 53, F-38041 Grenoble Cedex 9, France.

E-mail: guy.delrieu@hmg.inpg.fr ing this event and the economic damage is estimated at 1.2 billion euros, that is, about 1 billion U.S. dollars (Huet et al. 2003). Flash flooding is certainly the most destructive natural hazard in the western Mediterranean region where heavy rainfall events are rather common: for instance, an exhaustive inventory (Jacq 1994) listed 144 rain events having generated daily precipitation amounts greater than $190 \mathrm{~mm}$ during the 1958-94 period in southern France.

The factors conducive to such heavy precipitation 
events are the following: (i) the Mediterranean Sea acts as a reservoir of energy and moisture for the lower layers of the atmosphere, especially at the end of summer and beginning of fall, when the sea is still warm; (ii) at the synoptic scale, upper-level cold troughs generally extending from the United Kingdom to the Iberic Peninsula generate a southerly flow that both advects the warm and moist air masses from the Mediterranean Sea toward the coast, and helps to destabilize these air masses; (iii) the pronounced relief of the Mediterranean region, with the Alps, Pyrenees and Massif Central Mountains, triggers convection and also channels the low-level flows inducing low-level convergence, which contributes to the release of convective instability.

Heavy precipitation in this region can be the result of either convective or nonconvective processes, or a combination of both (Rivrain 1998; Miniscloux et al. 2001; Anquetin et al. 2003; Ducrocq et al. 2002). Large amounts of precipitation can accumulate over several day-long periods when one or several frontal perturbations are slowed down and enhanced by the relief of the Massif Central and the Alps. In some cases, large amounts of precipitation can even be observed in a few hours when an MCS stays over a given area. Frequently, these quasi-stationary MCSs are backward regenerative systems that take on a V shape in the infrared satellite imagery or in the radar imagery. Backward regeneration is evidenced by a continuous generation of new cells at the tip of the $\mathrm{V}$, whereas the mature and old cells are advected toward the $\mathrm{V}$ branches. The $\mathrm{V}$ shape results from the interaction of the convection with the upper south to southwesterly diffluent environmental flow that prevails generally during these episodes. These events are especially productive in terms of rain due to their high intensities and spatial stationarity.

Following the Mesoscale Alpine Programme (Bougeault et al. 1998, 2001), the Cévennes-Vivarais Mediterranean Hydrometeorological Observatory (OHM-CV is the French acronym) is a research initiative aimed at improving the understanding and modeling of the Mediterranean intense rain events that frequently result in devastating flash floods. In 2002, the OHM-CV was labeled as the Environment Research Observatory (ORE) by the French Ministry of Research. A primary objective of the observatory is to bring together the skills of meteorologists and hydrologists, modelers and instrumentalists, researchers and practitioners, to cope with these rather unpredictable events. The OHM-CV observation strategy, described in section 2, consists of three complementary lines of effort: (i) detailed, long-lasting, and modern hydrometeorological observation over part of the region of interest, the Cévennes-Vivarais region; (ii) postflood investigation after the major events occurring over the entire French Mediterranean region, and (iii) use of historical information available on past floods.

In line with previously published flash-flood monographs (e.g., Smith et al. 1996; Ogden et al. 2000), the present paper aims at documenting the 8-9 September 2002 catastrophic event with a description of the meteorological situation at the synoptic scale (section 3 ), radar and rain gauge rainfall observations (section 4), and hydrological observations in the affected areas (section 5). An overview of the ongoing OHM-CV meteorological and hydrological research projects is finally presented in section 6 . One of the main objectives is to develop a coupled hydrometeorological modeling approach by using nonhydrostatic, high resolving, meteorological models, together with distributed hydrological models, in order to obtain an integrated forecast of the phenomenon of interest.

\section{The OHM-CV observation strategies}

Due to the difficulty in observing rare hydrometeorological events, a three-fold observation strategy has been defined for the OHM-CV, as described in this section.

\section{a. A pilot site in the Cévennes-Vivarais region}

The Cévennes-Vivarais region (Fig. 1) was selected for implementing detailed and long-lasting hydrometeorological observation with modern instrumentation. Since this region is especially subject to flash floods, it is already well instrumented with operational observation systems. A difficulty arises from the fact that the operational instrumentation is managed by several weakly connected meteorological and hydrological services having their own meteorological objectives and practices. A first ongoing action of the OHM-CV thus concerns the creation of a research database for gathering, normalizing, examining, and archiving the operational data. This effort started in 2000 and is planned to last for at least $10 \mathrm{yr}$ in order to document a broad sample of rain events with a rich and rather stable observation system. During the period 2000-02, 22 rain events, with rain amounts greater than $50 \mathrm{~mm}$ day $^{-1}$ at some locations in the region of interest, were processed and archived.

Within the $160 \times 200 \mathrm{~km}^{2}$ Cévennes-Vivarais window, there are currently (i) three weather radars of the Météo-France ARAMIS network located at Nîmes, Bollène, and Sembadel; (ii) two networks of about 400 daily rain gauges and 160 hourly rain gauges; and (iii) a network of about 45 water level stations. The rain gauge and water level networks belong to no fewer than five services specializing in weather and environmental surveying and flood alerts. Besides the rainfall and hydrological datasets, the OHM-CV also benefits from the Météo-France meteorological datasets (radio soundings, analyses of the operational model, etc.). The operational observation system will be progressively upgraded in the coming years: for instance, the weather radar scanning strategies and processing techniques developed during the Bollène 2002 experiment (see section 6) are hoped to be generalized to all the radars of 


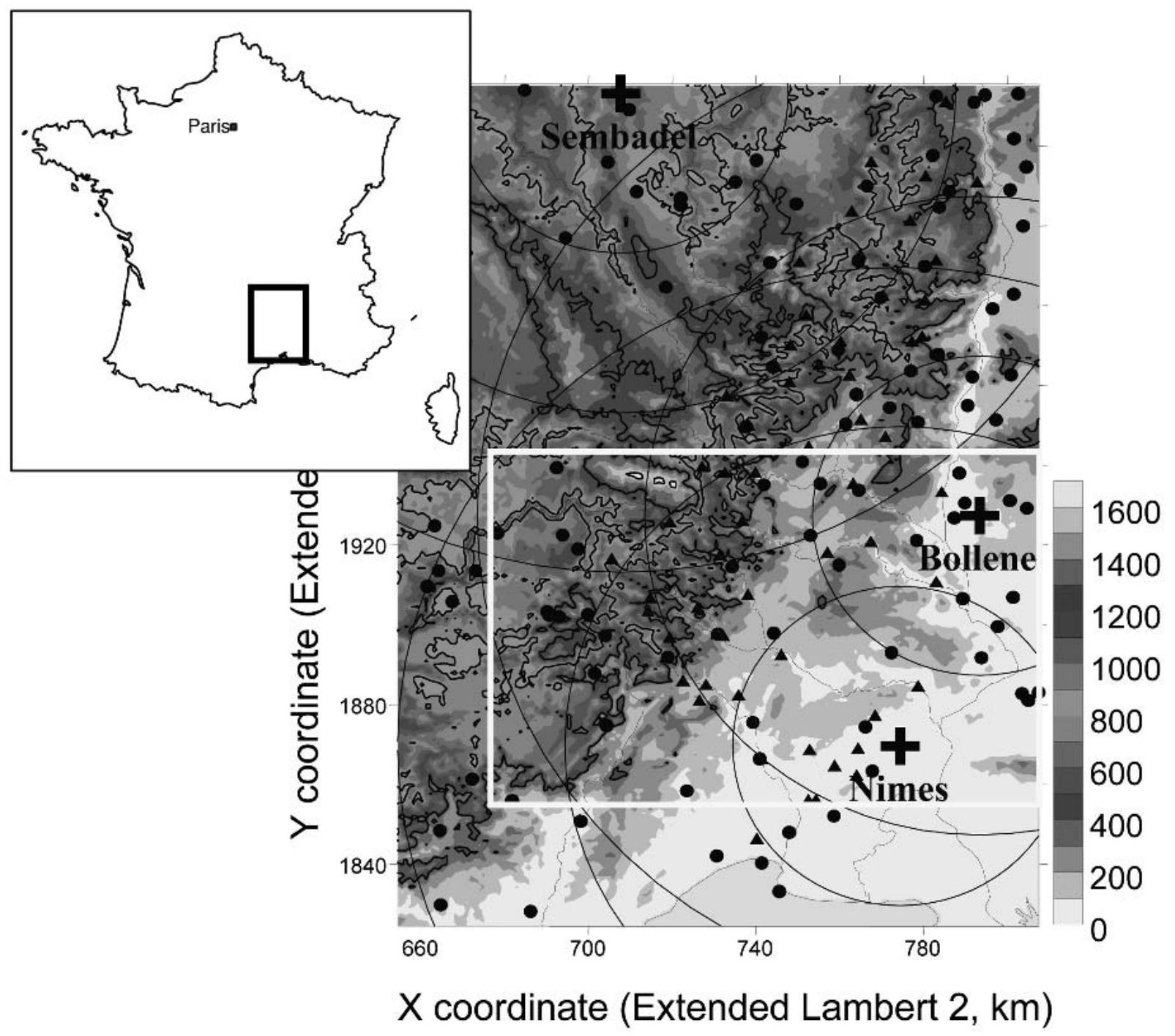

FIG. 1. Location of the OHM-CV Cévennes-Vivarais window in France. The shaded map presents the terrain elevation data and the main Cévennes rivers. In terms of geology, the mountainous part of the region (northwestern portion of the map) corresponds to the Primary era formations of the Massif Central (e.g., granite, schists, etc.) while sedimentary formations dominate in the Rhone Valley region (southeastern portion of the map) with, in places, karstified limestones. Also shown are the positions of the three Météo-France weather radar systems in Nîmes, Bollène, and Sembadel (crosses and 40-km range markers) and the hourly rain gauge network (black triangles and dots, depending on the data provider). The light gray box delineates the region affected by the 8-9 Sep 2002 rain event.

the Arc Méditerranéen ARAMIS network; a research action is also devoted to developing remote sensing techniques for discharge measurement during floods (Creutin et al. 2003) such as surface flow velocimetry using PIV or radar techniques; and a specific research action is also dedicated to GPS meteorology with the objective of assessing the atmospheric water vapor inflow using such devices (Walpersdorf et al. 2001).

\section{b. Postevent investigations on flash floods occurring in the French Mediterranean region}

Due to the rarity of extreme events, it is important to develop a strategy for observing them wherever they occur and not only in places where refined observation systems actually exist. This observation strategy was initiated in France for recent flash floods (Gaume et al. 2003, 2004). On this basis, a postevent investigation has been performed by several research teams associated with the OHM-CV for the 8-9 September 2002 rain event in the Gard region. Basically, the procedure aims at estimating maximum discharges by means of water level marks for the head watersheds (sizes in the range of $10-200 \mathrm{~km}^{2}$ ) in the affected areas. It also consists of interviewing witnesses to document the chronology of the flood - that is, time and duration of the flooding for particular levels. These field observations are complemented by the collection of all available rainfall data. 
The data analysis consists of using a robust hydrological model for testing the consistency between the estimated rainfall and discharge over the affected areas. This allows various hypotheses to be tested concerning the dominant hydrological processes during flash floods (see section 5).

\section{c. Use of historical information on Mediterranean flash floods}

The first two observation strategies rely on data recently collected or to be collected in the future. Obviously, a lot of information is already available on flash floods that have occurred in the Mediterranean region. These historical datasets allow a better quantification of rain and flood frequencies, crucial information for both town and country planning issues and climate studies. A considerable body of work was devoted to analyzing rainfall and discharge time series obtained during the recent systematic observing period (from 1960 to the present) with the objective of mapping extreme rainfall and discharge parameters (e.g., Neppel 1997, for the Languedoc-Roussillon region; Bois et al. 1997, for the Cévennes-Vivarais region; Kieffer and Bois 1997, for the French and Italian Alps). Promising multidisciplinary studies also are being developed between historians, hydraulicians, and hydrologists in order (i) to identify in various historical data sources the existence of past floods and the water levels reached in the period 1600-1950, (ii) to convert this level information into discharge estimations using hydraulic modeling, and (iii) to perform refined statistical analyses of these heterogeneous time series. Use of hydrological paleoindicators may allow detection and quantification of older floods. On this subject, we can mention the European project SPHERE (Systematic, Palaeoflood, and Historical Data for the Improvement of Flood Risk Estimation; Benito et al. 2004) and, more specifically, historical and paleoflood analyses for the Ardèche watershed (Naulet et al. 2004; Sheffer et al. 2004) located within the Cévennes-Vivarais window.

The next three sections aim at documenting the 8-9 September 2002 catastrophic rain event, which occurred within the well-instrumented CévennesVivarais window, thus offering very rich datasets for this particular case study.

\section{Meteorological context of the 8-9 September 2002 rain event}

The first convective cells formed around 0400 UTC on 8 September 2002 over the Mediterranean Sea. The convection progressed northward and inland to form an MCS over the Gard region after 0800 UTC 8 September 2002. The MCS stayed over the same region until 1200 UTC 9 September 2002. The majority of the high surface rainfall amounts were induced by this quasistationary MCS.
Figure 2 presents the surface pressure and $500-\mathrm{hPa}$ height analyses at 1200 UTC 8 September 2002, that is, at the beginning of the precipitation period over southeastern France. An upper-level cold low centered over Ireland extended meridionally to the Iberian Peninsula and resulted in diffluent southwesterly flow over southeastern France (Fig. 2a). Figure 3 presents the height of the dynamic tropopause estimated by the isosurface of 1.5 PVU (potential vorticity unit: $1 \mathrm{PVU}=10^{-6} \mathrm{~m}^{2} \mathrm{~s}^{-1}$ $\mathrm{K} \mathrm{kg}^{-1}$ ). The low elevation of this isosurface indicates intrusion of stratospheric air in the troposphere. At 1200 UTC (Fig. 3a), associated with the upper trough, was an elongated filament of intruded stratospheric air with some substructures along its eastern flank and at its southern tip that revealed short-wave troughs circulating around the main upper low. At the surface and ahead of the trough, a front undulated over western France (Fig. 2c). Convection formed well ahead of the surface cold front in the warm sector. This region is characterized by moist and warm low-level southeasterly flow as seen in the equivalent potential temperature field (Fig. 4a). Prior to the development of convection, the atmosphere was conditionally unstable as evidenced by a significant CAPE value on the midnight Nîmes radiosounding of 8 September 2002 (about $850 \mathrm{~J}$ $\mathrm{kg}^{-1}$ for the CAPE based on the most unstable parcel; Fig. 5). Precipitable water computed for this radiosounding shows that the humidity content of the atmosphere was already high $(33 \mathrm{~mm})$. This precipitable water value is on the upper $10 \%$ of the distribution of precipitable water for the Nîmes radiosounding for September between 1994 and 2003, the average value being of $22 \mathrm{~mm}$. After the onset of convection, the 1200 UTC radiosounding is almost saturated with a precipitable water value reaching the upper $5 \%$ of the distribution of precipitable water for the 1994-2003 Nîmes radiosoundings; the CAPE value was reduced to about $400 \mathrm{~J} \mathrm{~kg}^{-1}$, still indicating a potential for convective development.

During the afternoon of 8 September 2002, the surface cold front slowly progressed eastward. The lowlevel flow accelerated around the southern Alps resulting in increased low-level convergence downstream in southeastern France (Fig. 4b). At the same time, the main upper-level trough swung into a northwestsoutheast orientation (Figs. $2 b$ and $3 c$ ), leading to a south-southwesterly upper-level flow over southeastern France. Circulating around it, a short-wave trough, characterized by the southern substructure of intruded stratospheric air, translated northeastward above the Bay of Biscay at midnight (Fig. 3b); this resulted in an increase of the upper-level divergent flow over southeastern France that provided additional upward motion over the low-level confluence zone. As the surface front passed over the Gard region (Fig. 2d), it contributed to the heavy precipitation, but also swept the convective activity out of the affected region. The moist low-level flow shifted easterly and decayed, whereas low equiva- 

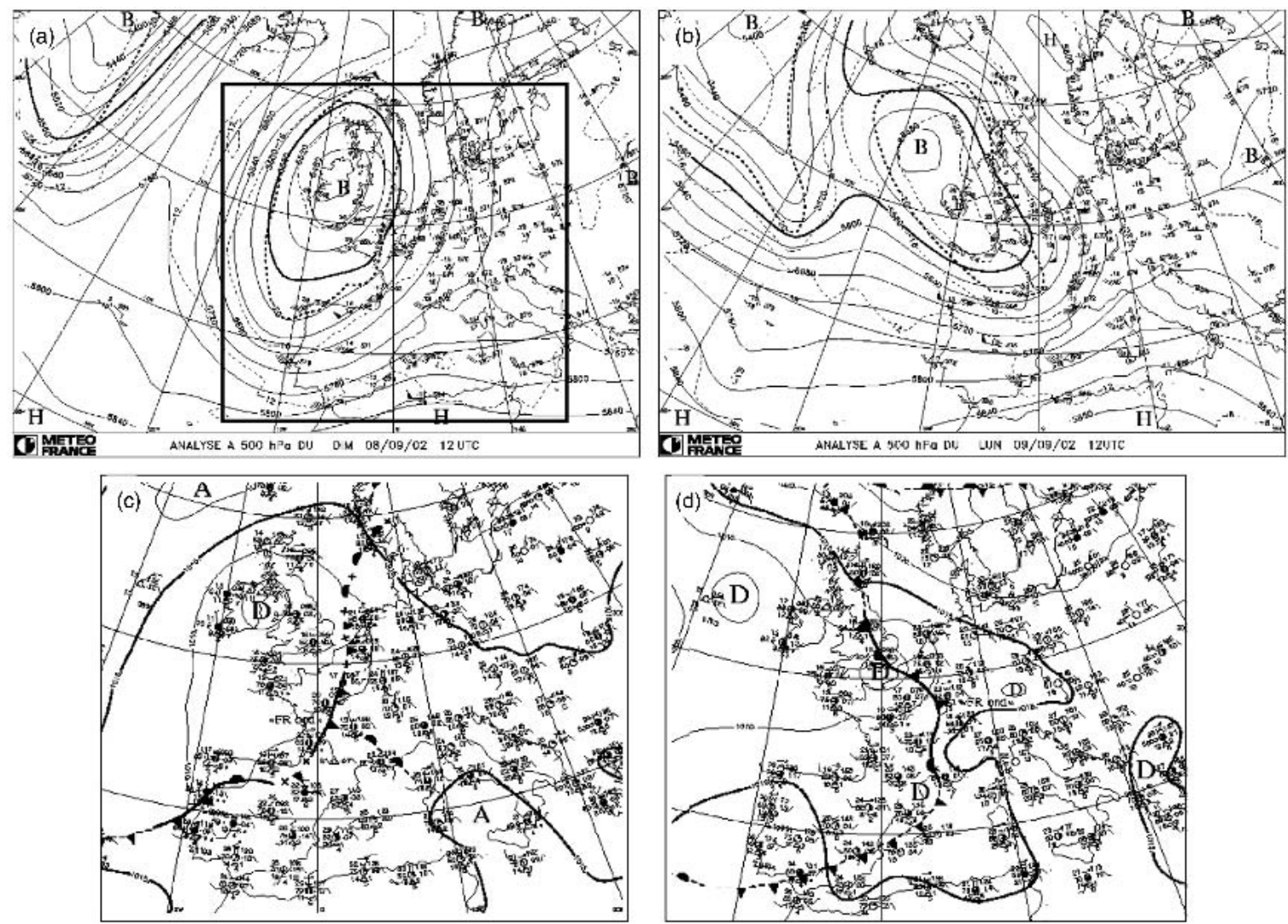

FIG. 2. Surface and 500-hPa height analyses of the French meteorological center (Météo-France) at (a), (c) 1200 UTC 8 Sep 2002 and (b), (d) 1200 UTC 9 Sep 2002. (a), (b) For 500-hPa analyses, geopotentials (in m) and temperature (in ${ }^{\circ} \mathrm{C}$ ) are drawn, respectively, as solid and dashed lines ( $\mathrm{H}$ for high center and B for low center of geopotential). (c), (d) Surface analyses are shown over the box drawn in (a); the sea level pressure (in $\mathrm{hPa}$ ) is shown by solid lines (A for high centers and $\mathrm{D}$ for low centers of sea level pressure).

lent potential temperature air associated with the westerly low-level winds behind the front affected the Gard region (Fig. 4c), resulting in less favorable conditions for further convective development.

\section{Rainfall observation during the 8-9 September 2002 event}

We will concentrate first on the rain accumulations observed during the event with the daily rain gauge network and the two Météo-France weather radars located in Nîmes and Bollène. Then, the time and space variability of rainfall will be described using radar data and some illustrative radar and rain gauge hyetographs at an hourly time step.

\section{a. Rain amounts at the event time scale}

The rain gauge map presented in Fig. 6a was established using the 2-day accumulated rain amounts of the daily rain gauge network, which numbers 189 sensors over the considered region of $140 \times 90 \mathrm{~km}^{2}$ (i.e., a density of about one rain gauge for $67 \mathrm{~km}^{2}$ ). Note that the network density is not homogeneous and that some "holes" are evident in central, southeastern, and northwestern portions of the region. The rain event lasted approximately $28 \mathrm{~h}$ : between 0800 UTC 8 September 2002 and 1200 UTC 9 September 2002. The kriging technique (Creutin and Obled 1982; Lebel et al. 1987) was used for mapping the individual records after identification of the variogram function, which characterizes the spatial structure of the rain field. The rain climatology of the region (Bois et al. 1997) suggests that the rain fields may possess a significant anisotropy at the daily time scale that was accounted for by performing the kriging with an anisotropic variogram. The identified range values (mean decorrelation distances of the rain gauge amounts) are $65 \mathrm{~km}$ in the direction toward $30^{\circ}$ (i.e., toward the north-northeast), roughly parallel to the mountain range, and $40 \mathrm{~km}$ in the orthogonal direction (about $120^{\circ}$ ).

The rain amounts derived from the Nîmes and Bollène radar systems are displayed in Figs. $6 b$ and $6 c$, respectively. The Météo-France operational scanning protocols, elevation angle compositing, and data processing procedures (see Table 1) were employed to es- 

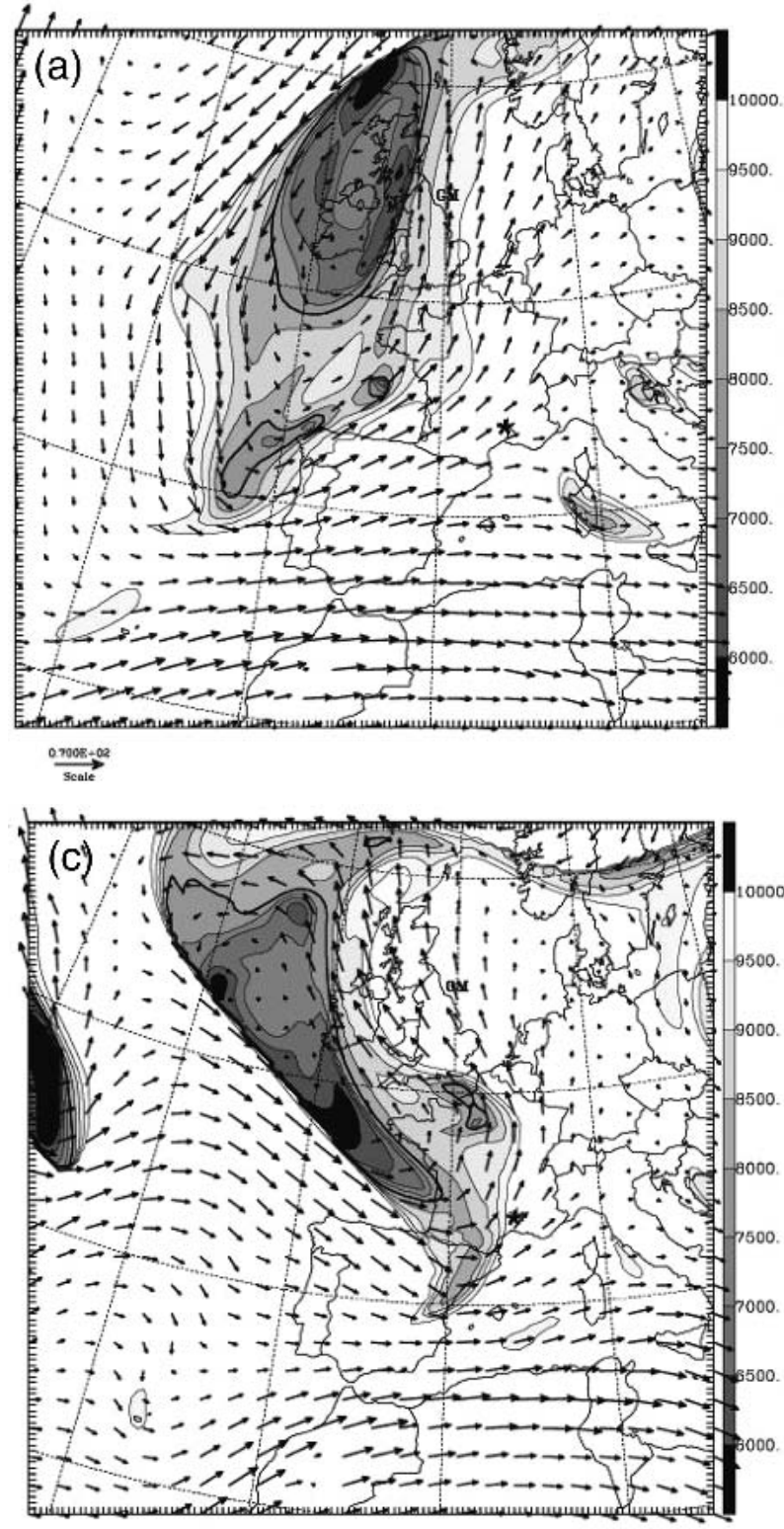

tablish these maps. In addition to these procedures, a calibration factor derived from radar-rain gauge comparisons performed at the event time scale in the vicinity of the radar sites (at ranges less than $30 \mathrm{~km}$ ), was applied uniformly in time and space to obtain the displayed radar rain amounts. This necessary correction (additive corrections of -1.34 and $1.37 \mathrm{dBZ}$ for the Nîmes and Bollène radar reflectivities, respectively) is mainly aimed at compensating for an electronic calibration default. It obviously accounts for other sources of bias-for example, for an ill-suited $Z-R$ relationship multiplicative coefficient. Note that the two radar maps are pretty consistent regarding the amounts and location of the main precipitation cores. This good overall consistency is an expected result owing to the fact that

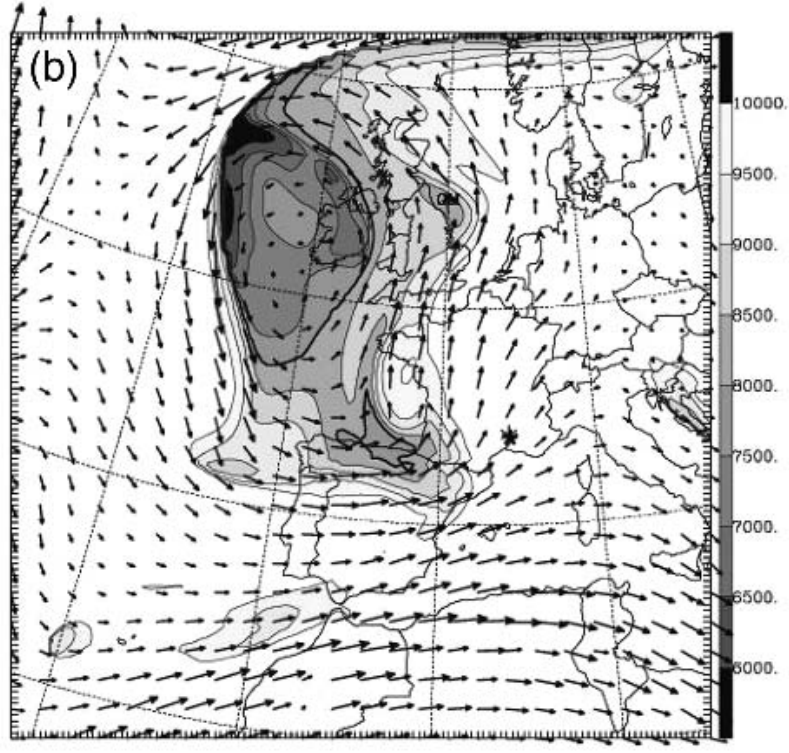

FIG. 3. Height (in $\mathrm{m}$, with grayscale at the right of the panels) of the dynamic tropopause, diagnosed as the isosurface of 1.5 potential vorticity unit ( $1 \mathrm{PVU} \equiv 10^{-6} \mathrm{~m}^{2} \mathrm{~s}^{-1} \mathrm{~K} \mathrm{~kg}^{-1}$ ), superimposed on the wind vectors at the same level [unit vector length at the bottom of (a) corresponding to $70 \mathrm{~m} \mathrm{~s}^{-1}$ ], from the ARPEGE analyses at (a) 1200 UTC 8 Sep, (b) 0000 UTC 9 Sep, and (c) 1200 UTC 9 Sep 2002. The location of the Nîmes radiosounding station (Fig. 5) is indicated by the star. the rain event affected a region of good visibility (Pellarin et al. 2002) for both S-band radar systems. More quantitatively, the agreement between the three sets of raw rain data is indeed good with bias values of 0.82 and 1.03 (ratio of the average radar and rain gauge values), determination coefficients of 0.92 and 0.83 , Nash coefficients of 0.79 and 0.80 for the Nîmes and Bollène rain estimates, respectively, compared to the rain amounts measured by the daily rain gauge network. A detailed presentation of the mentioned criteria can be found in Berne et al. (2004). The significant remaining bias of the Nîmes radar data over the affected region can be related to the effects of the relief (screening) and the vertical structure of the reflectivities, which are not corrected for by the considered operational procedures. 

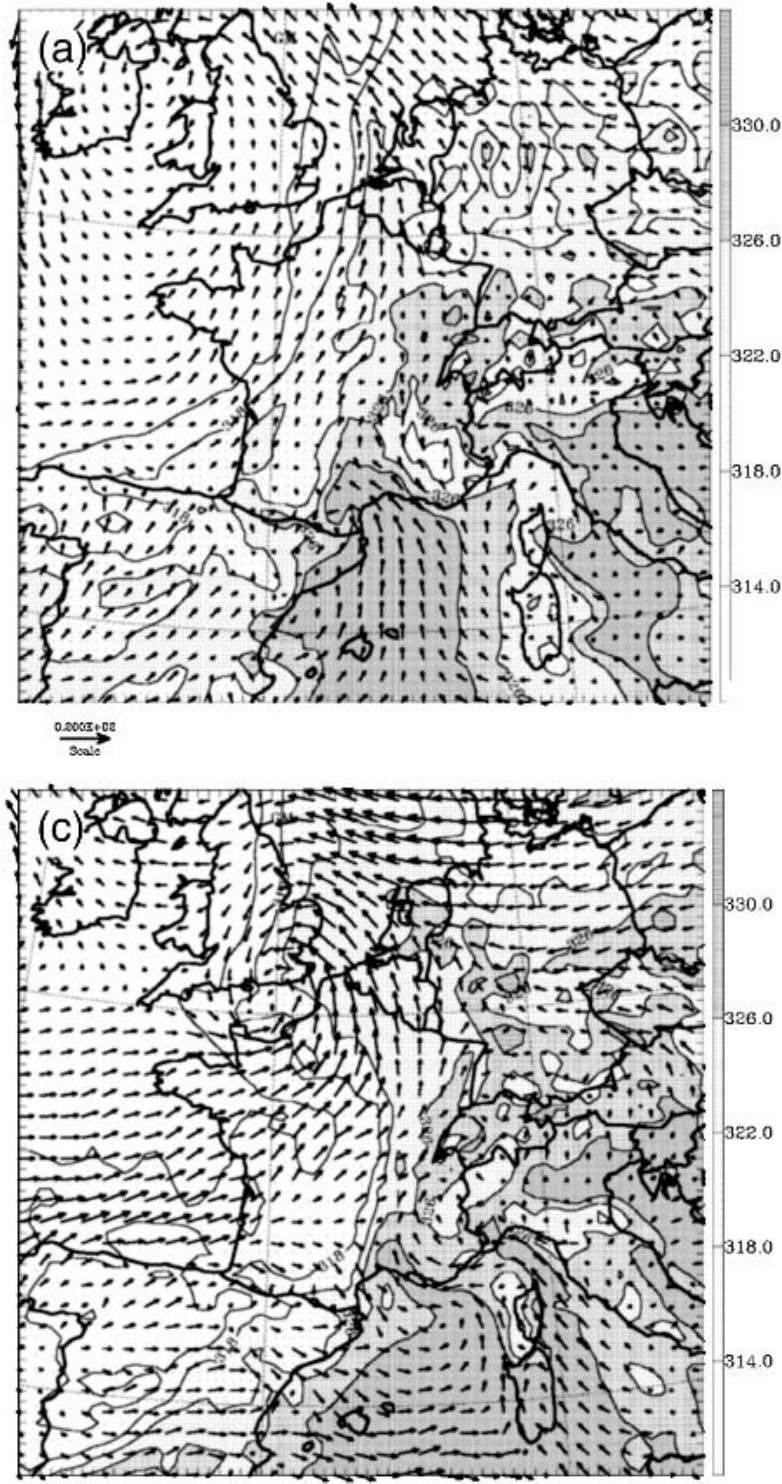

The greater dispersion of the Bollène radar estimates (lower determination coefficient value) is mainly related to the effects of residual ground clutter over the Cévennes mountain ridge for this radar system.

Figures $6 \mathrm{~d}$ and $6 \mathrm{e}$ present the results obtained by merging the radar and the rain gauge datasets. The merging method is a simple spatially variable calibration technique based on the $G / R$ ratios, where $G$ and $R$ represent the rain gauge and radar rain amount values, respectively, at the event time scale. The $G / R$ ratios are interpolated in space thanks to the kriging technique. Inference of the variogram of the ratios is the prerequisite for using this method. The identified variograms present a range of about $60 \mathrm{~km}$ for both radar systems. No significant nugget effect (i.e., a non-null value when the interdistance tends toward 0 ) is observed. This significant spatial structure of the ratios indicates that an

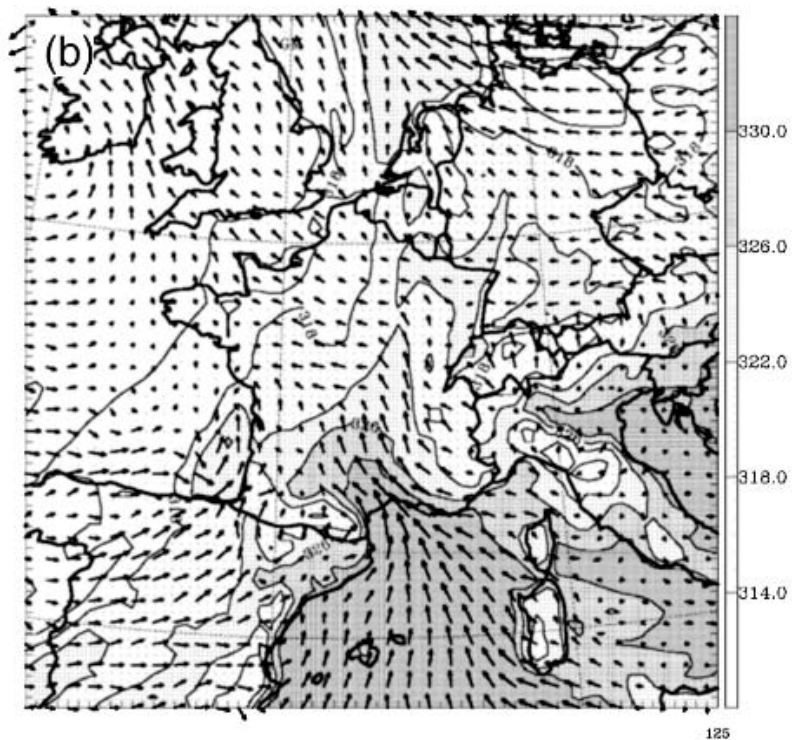

FIG. 4. Equivalent potential temperature (in K, grayscale at the right of the panels) and wind vectors (unit vector length at the bottom of (a) corresponding to $20 \mathrm{~m} \mathrm{~s}^{-1}$ ) at a height of about $30 \mathrm{~m}$ above the topography, from the ARPEGE analyses at (a) 1200 UTC 8 Sep, (b) 0000 UTC 9 Sep, and (c) 1200 UTC 9 Sep 2002.

improvement can be expected by using the spatially variable calibration technique with respect to the rain fields produced by each observation system alone. A detailed comparison of Figs. 6d and 6e confirms an appreciable gain in terms of consistency between the maps derived from the two radar datasets. Three rain patterns with rain totals greater than $400 \mathrm{~mm}$ are visible inside a pattern of rain amounts greater than $200 \mathrm{~mm}$ covering most of the considered window. The maximum values exceeded $600 \mathrm{~mm}$ in the region of Anduze and Alès.

Figure 7 summarizes the results obtained by some of the rain estimation approaches used in terms of exceedance areas; that is, the areas over which a given amount of rainfall was exceeded in the region of interest. The spatial calibration method provides very consistent results for the two radar systems with areas of about 5500, 


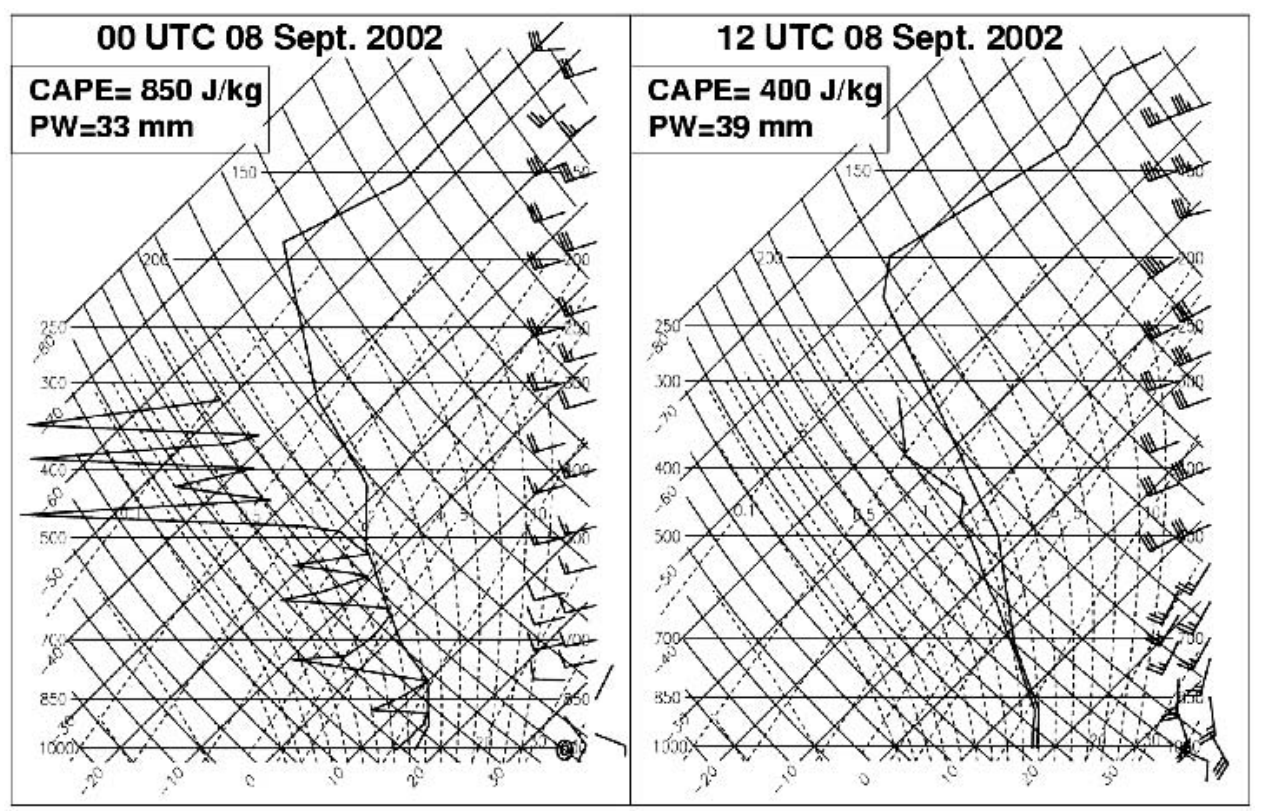

FIG. 5. Radiosoundings at Nîmes location at (left) 0000 and (right) 1200 UTC 8 Sep 2002. In the upper-left corners of the panels, CAPE stands for convective available potential energy $\left(\mathrm{J} \mathrm{kg}^{-1}\right)$ and PW for precipitable water $(\mathrm{mm})$. The CAPE computation is based on the most unstable parcel.

1600 , and $170 \mathrm{~km}^{2}$ for the 200-, 400-, and 600-mm thresholds, respectively. As a result of the low density of the daily rain gauge network in some portions of the region of interest, the kriging technique slightly overestimates the exceedance areas in the [100-300 $\mathrm{mm}]$ rain threshold range and significantly underestimates them for the rain thresholds greater than $400 \mathrm{~mm}$. Also shown in Fig. 7 are similar evaluations, based on daily rain gauge data, for two of the most devastating rain events that occurred in the Languedoc-Roussillon region, France, during the last 40 yr. The exceedance areas for the 200- and 400-mm thresholds are equal to 2800 and $30 \mathrm{~km}^{2}$, respectively, for the 29-30 September 1958 rain event in the Cévennes region and of 4000 and $1500 \mathrm{~km}^{2}$, respectively, for the 12-13 November 1999 rain event in the Aude region (Neppel 1997; Gaume et al. 2004). The 8-9 September 2002 Gard event is therefore particularly remarkable by its spatial extent.

\section{b. Spatial and temporal distribution of the rainfall}

The dynamics of the rain event were analyzed using radar animations of both the instantaneous rain rates at the 5-min time step and the accumulated rain amounts up to a given instant. To summarize this study, Fig. 8 presents the spatially calibrated radar rain amounts during the three phases that can be clearly distinguished during the 8-9 September 2002 rain event.

\section{1) Phase 1: (0800-2200 UTC 8 September)}

After an initial period (0600-0900 UTC) where convection develops inland and starts producing rather uni- form rain amounts over the region, the MCS becomes stationary after 0900 UTC and takes a southwestnortheast orientation. The convective part of the MCS produces rain amounts greater than $200 \mathrm{~mm}$ in less than $12 \mathrm{~h}$ in the northwest region of the city of Nîmes, a region of plains corresponding to the lower parts of the Gardon and Vidourle watersheds.

\section{2) Phase 2: (2200 UTC 8 September-0400 UTC 9 SEPTEMBER)}

After 2200 UTC, the MCS pivots progressively to a south-north orientation, moves toward the upper part of the Gardon and Cèze watersheds, and becomes stationary at the limit of the Cévennes Mountain ridge. It produces sustained rain rates during $6 \mathrm{~h}$, which leads to the well-defined rain pattern shown in Fig 8.

\section{3) Phase 3: (0400-1200 UTC 9 September)}

During the morning of 9 September 2002, the cold front passes and sweeps the MCS out of the region. As usual, high rain rates are observed during this phase but, resulting from the rapid storm displacement, the total rain amounts remain limited to about $100 \mathrm{~mm}$, with a rather uniform spatial distribution over the region. However, since the storm moves from upstream to downstream over the river network, the additional precipitation may have had a significant hydrological impact.

The consistency of the rain estimates during these three phases with the two spatially calibrated weather radar datasets is good (Fig. 8). To further illustrate the 


\section{RAIN GAUGE NETWORK}

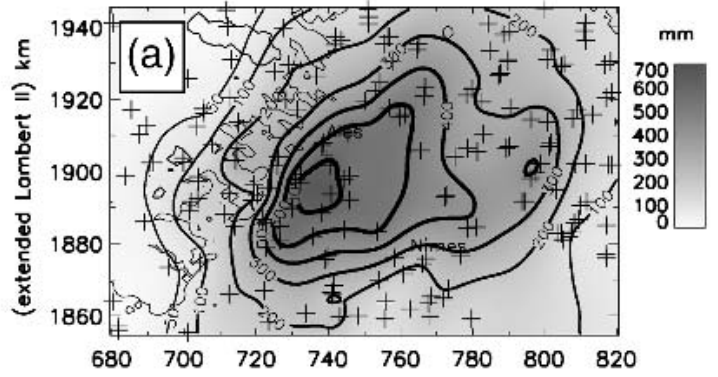

RADAR DATA: UNIFORM CALIBRATION NIMES

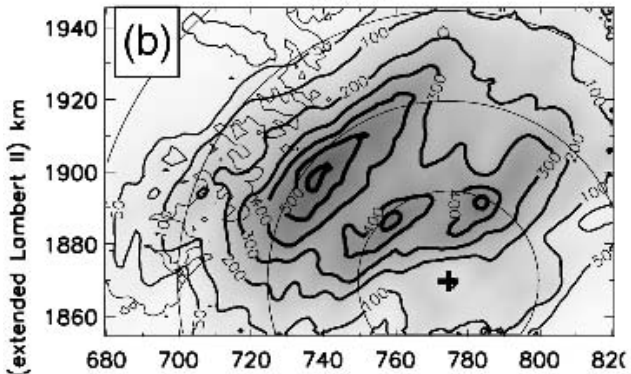
BOLLENE

RADAR DATA: SPATIAL CALIBRATION
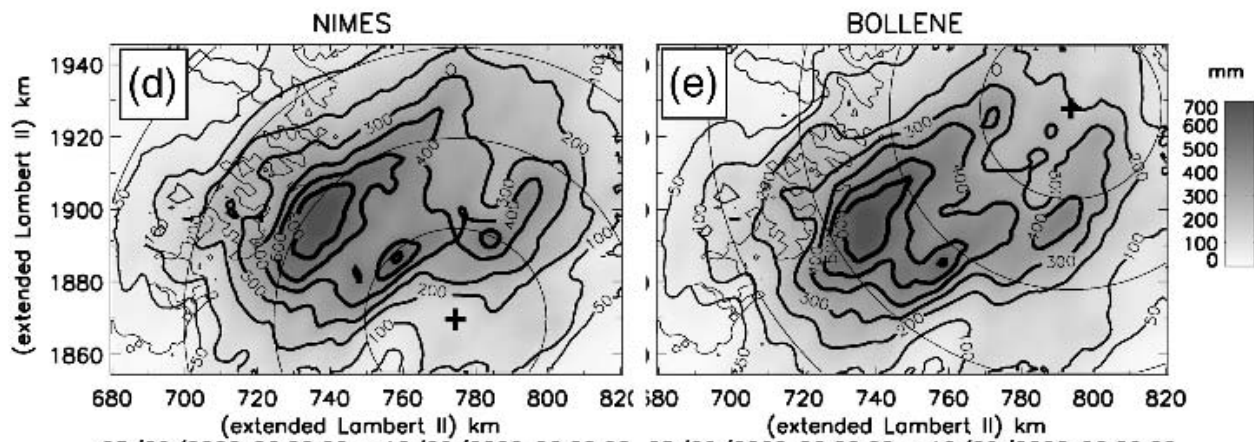

08/09/2002 06:00:00->10/09/2002 06:00:00 08/09/2002 06:00:00->10/09/2002 06:00:00

FIG. 6. Maps of the total rain amounts observed during the 8-9 Sep 2002 rain event in the Gard region (the corresponding geographic area is delineated by the light gray box in Fig. 1). (a) The map is obtained by applying the kriging interpolation technique to the daily rain gauge network with an anisotropic variogram. (b) and (c) These maps correspond to the datasets of the Nîmes and the Bollène weather radar systems, respectively, calibrated uniformly by means of radar-rain gauge comparisons performed in the vicinity of the radar sites. (d) and (e) These maps correspond to the datasets of the Nîmes and the Bollène weather radar systems, respectively, spatially calibrated using the daily rain gauge measurements. The "+" symbols in (a) refer to the daily rain gauge locations.

time structure of the rain event and assess the quality of the different sources of data, Fig. 9 provides some rain gauge and radar hyetographs observed at the hourly time step in different parts of the region. The Anduze and Alès hyetographs, with total rain gauge amounts of 697 and $500 \mathrm{~mm}$, respectively, are typical of the rainfall that occurred during phases 2 and 3 in the upper part of the Gard watershed. The rain gauge measurements at the two sites consistently depict a period of high rain rates (average value of about $40 \mathrm{~mm} \mathrm{~h}^{-1}$ ) between 2200 and 0400 UTC the next morning, leading to total rain amounts of about $250 \mathrm{~mm}$. Then, a brief calm of $1 \mathrm{~h}$ is followed by a rainy period of about $2 \mathrm{~h}$ with even stronger rain rates (e.g., $140 \mathrm{~mm}$ measured in $1 \mathrm{~h}$ by the Anduze rain gauge!). This final burst corresponds to the passage of the cold front over that area. The Remoulins and Chateauneuf-du-Pape hyetographs are typical of the rainfall that occurred in the Gard plains with two distinct peaks during phases 1 and 3 separated by a calm of about $12 \mathrm{~h}$. Like the Alès and Anduze 
TABLE 1. Radar parameters and data processing.

\begin{tabular}{|c|c|c|}
\hline Location & $\begin{array}{l}\text { Nîmes } \\
\text { Manduel }\end{array}$ & Bollène \\
\hline \multicolumn{3}{|l|}{ Transmitter-receiver } \\
\hline Peak power $(\mathrm{kW})$ & 600 & 600 \\
\hline Frequency (GHz) & 2.8 & 2.8 \\
\hline $\operatorname{PRF}(\mathrm{Hz})$ & 330 & 250 \\
\hline Pulse width $(\mu s)$ & 2 & 2 \\
\hline $\begin{array}{l}\text { Minimum detectable signal } \\
\text { MDS }(\mathrm{dBm})\end{array}$ & -103 & -113 \\
\hline Dynamic range $(\mathrm{dB})$ & 80 & 80 \\
\hline \multicolumn{3}{|l|}{ Antenna } \\
\hline Diameter (m) & 4.0 & 6.2 \\
\hline $\begin{array}{l}\text { Beamwidth at half-power } \\
\text { point }\left(^{\circ}\right)\end{array}$ & 1.8 & 1.28 \\
\hline Power gain $(\mathrm{dB})$ & 40.0 & 42.5 \\
\hline \multicolumn{3}{|l|}{ Operational data processing } \\
\hline Elevation angles used $\left(^{\circ}\right)$ & $2.6,1.3,0.6$ & $1.8,1.2,0.8$ \\
\hline Ground clutter (GC) removal & \multicolumn{2}{|c|}{$\begin{array}{l}\text { Operational GC reduction } \\
\text { technique based on } \\
\text { pulse to pulse reflectivity } \\
\text { variance threshold }\end{array}$} \\
\hline $\begin{array}{l}\text { Pseudo-CAPPI compositing } \\
\text { ranges }\end{array}$ & $\begin{array}{l}r_{1}=20 \mathrm{~km} \\
r_{2}=80 \mathrm{~km}\end{array}$ & $\begin{array}{l}r_{1}=35 \mathrm{~km} \\
r_{2}=75 \mathrm{~km}\end{array}$ \\
\hline Vertical profile of reflectivity & No & ction \\
\hline $\begin{array}{l}Z-R \text { relationship }\left(Z \text { in } \mathrm{mm}^{6}\right. \\
\left.\mathrm{m}^{-3} ; R \text { in } \mathrm{mm} \mathrm{h}^{-1}\right)\end{array}$ & $Z=$ & $R^{1.54}$ \\
\hline
\end{tabular}

cases, the MCS produced total amounts of about 250 $\mathrm{mm}$ in 5-6 h, during phase 1 . The rain rates corresponding to the cold front passage at about 1000-1100 UTC are significantly lower than the ones observed at

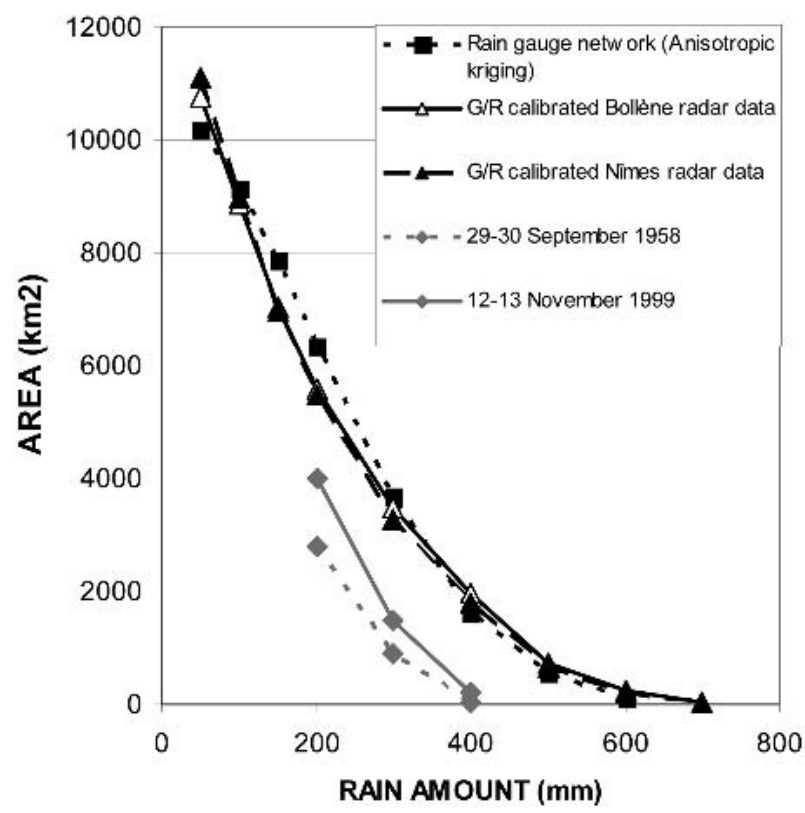

FIG. 7. Curves of exceedance areas for the 8-9 Sep rain event, i.e., the areas over which various rain thresholds were exceeded, using three rain estimation approaches (black curves). Similar results are displayed for the 29-30 Sep 1958 (Cévennes) and 12-13 Nov 1999 (Aude) historical rain events (gray curves).
Anduze and Alès, an indication of the decrease of the cold front activity as it progresses toward the east. The Barrage de la Rouvière hyetographs are representative of intermediate locations with an MCS contribution of about $250 \mathrm{~mm}$ between 1400 UTC 8 September and 0200 UTC 9 September, followed by a calm of 4-5 h and a brief and intense rain sequence during the cold front passage between 0600 and 0900 UTC.

The comparison of the radar and rain gauge hyetographs displayed in Fig. 9 calls for the following comments: 1) the covariation of the rain gauge and radar time series is rather good with coefficients of determination (the square of the correlation coefficient) in the range of 0.76 (Remoulins) up to 0.98 (Alès); 2) the covariation of the two radar time series is sometimes much better than that of the radar-rain gauge time series, for example, for Alès, Barrage de la Rouvière, and Remoulins. The latter result is certainly in great part due to the different measurement principles (in particular in terms of sampling) of the radar and rain gauge sensors. Such cross-comparisons are useful to detect sensor problems: for instance, since the rain estimates of the two radar systems are very similar, a malfunction (e.g., partial occlusion) is likely for the Remoulins rain gauge during phase 3 . A detailed radar-rain gauge analysis is beyond the scope of the present paper; however, the results presented here clearly indicate the overall consistency of the three sources of rainfall data. An ongoing action is realized in cooperation between Météo-France and several research laboratories (see section 6) to further improve the radar data processing by means of a full volumetric scanning strategy.

To summarize, the dynamics of the 8-9 September 2002 rain event presents the following characteristics: (i) the MCS typically produced rain amounts of 200$300 \mathrm{~mm}$ during periods of about $6 \mathrm{~h}$, (ii) the evolution of the synoptic situation induced a clear shift of the MCS between the Gard plains region toward the upstream part of the Gard watershed during the night of 8-9 September 2002, and (iii) in a third phase, the passage of the cold front brought additional rain amounts of about $100 \mathrm{~mm}$ with brief and violent bursts in the western part of the region. The rain event therefore presents a marked space and time structure: in the following section, we aim at documenting the hydrological response of the watersheds over all the region and try to find evidence of the rainfall signature in this response.

\section{Postevent hydrological investigation}

The 8-9 September 2002 rain event induced one of the most significant floods ever reported of the Gard, Cèze, and Vidourle Rivers (see Fig. 10 for location), and also produced remarkable flash floods of many upstream tributaries. The operational hydrological data available for these watersheds consists of 17 river stage 


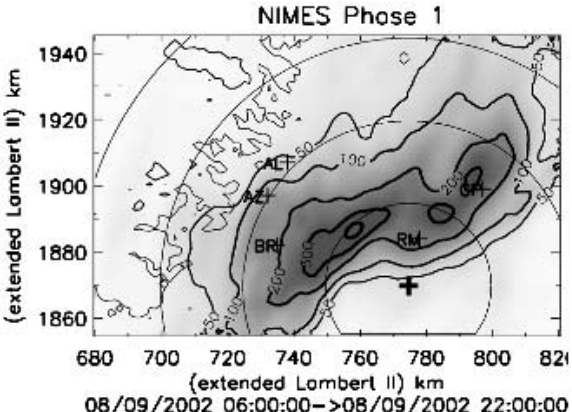

NIMES Phose 2

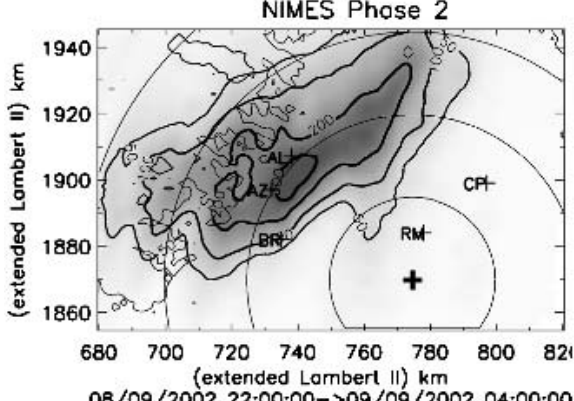

NIMES Phose 3

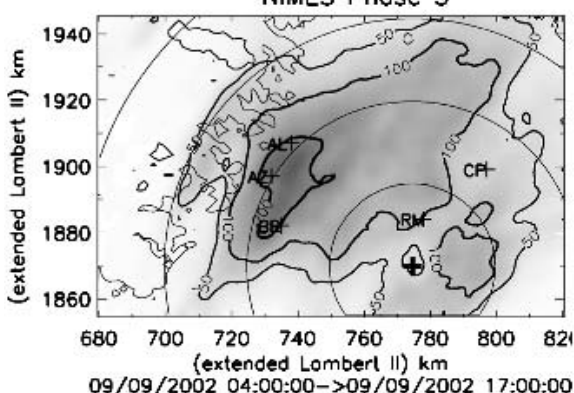

BOLLENE Phose 1

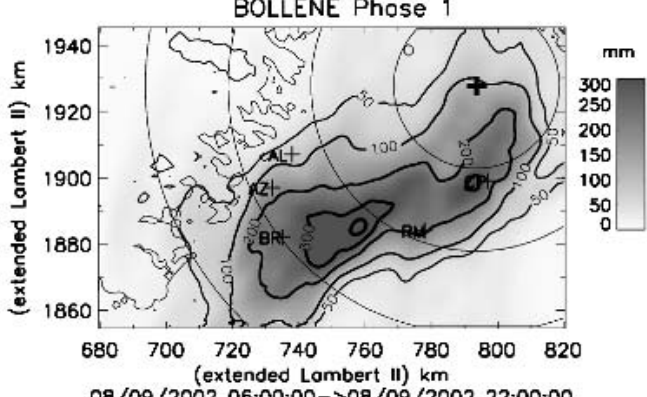

$08 / 09 / 2002$ 06:00:00->08/09/2002 22:00:00

BOLLENE Phose 2

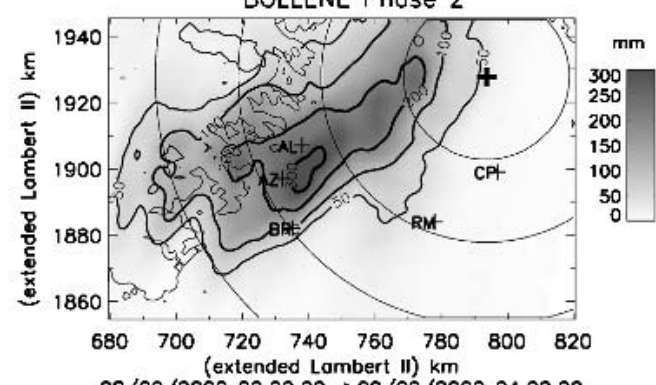

08/09/2002 22:00:00->09/09/2002 04:00:00

BOLLENE Phose 3

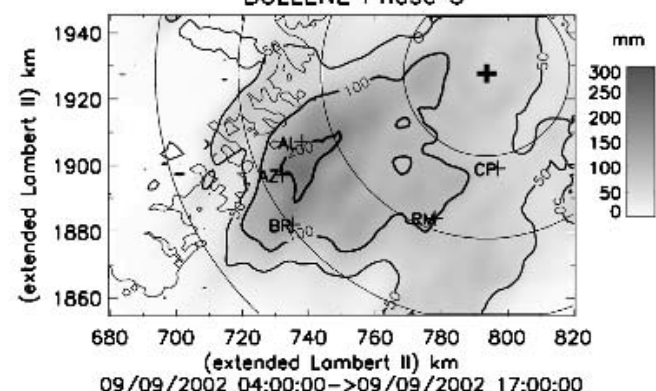

09/09/2002 04:00:00->09/09/2002 17:00:00

FIG. 8. Rain amounts $(\mathrm{mm})$ during the three main phases of the 8-9 Sep 2002 rain event, as discussed in section 4b. The displayed rain maps correspond to the (left) Nîmes and (right) Bollène weather radar data calibrated spatially by means of the daily rain gauge network measurements. The spatial calibration is kept constant in time. The locations of the five rain gauges of Alès (AL), Anduze (AZ), Barrage de la Rouvière (BR), Remoulins (RM), and Chateauneuf-du-Pape (CP) are shown (see section 4b and Fig. 9).

records that are located on the main streams. Some of the sensors, which are based on pressure measurement principles, were shown to significantly underestimate the observed high water levels. Some of them were destroyed during the flood. A study has therefore been commissioned by the Gard water authorities to critically analyze and correct these operational measurements as much as possible. In addition, an extensive postflood investigation was conducted during autumn and winter $2002-03$ by several research teams associated with the OHM-CV in order to collect information concerning the floods that occurred in the headwater tributaries of the Gard, Vidourle, and Cèze Rivers. In the following, we first present an overall view of the maximum discharge and peak time data collected and its relation with the spatial and temporal distribution of the rainfall. In the second part, attention is given to the study of the distinct hydrological behaviours of two watersheds.

\section{a. Spatial and temporal characteristics of the hydrological response}

During the postevent investigation, 143 witnesses were interviewed and 93 river cross sections were surveyed and the corresponding flood peaks estimated to assess the contribution of the headwater tributaries. To summarize the postevent investigation results, the estimated peak specific discharges of 17 watersheds with sizes in the range of 10 to $100 \mathrm{~km}^{2}$ are presented on a map of the region (Fig. 11), together with the 200-, 400-, and $600-\mathrm{mm}$ rain contours, while numerical values (spe- 

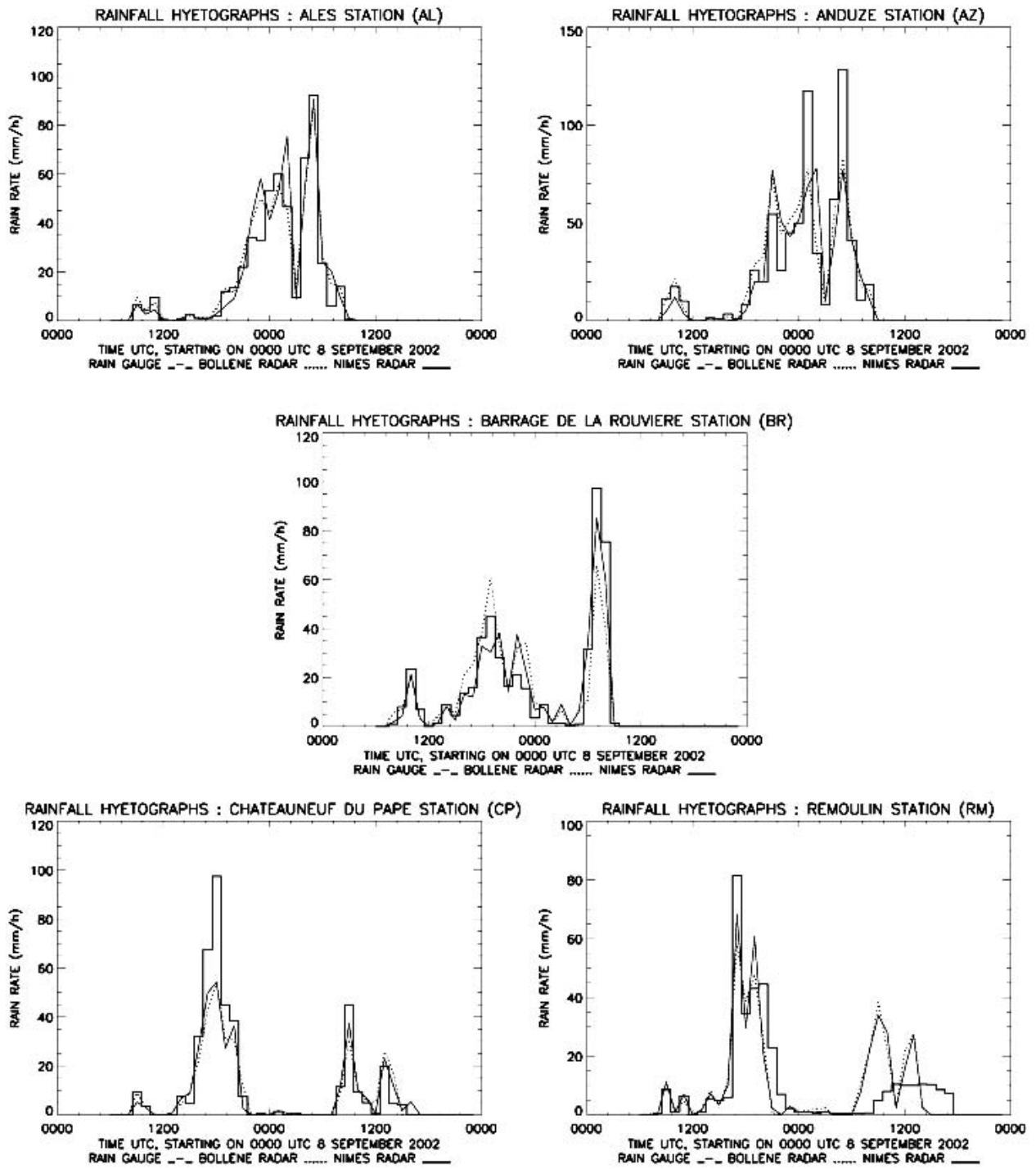

FIG. 9. Hourly hyetographs for the five rain gauge stations of Alès (AL), Anduze (AZ), Barrage de la Rouvière (BR), Chateauneuf du Pape (CP), and Remoulin (RM). See Fig. 8 for the corresponding locations. For a qualitative assessment, the rain gauge estimates are displayed together with the corresponding spatially calibrated Nîmes and Bollène radar estimates. Note that the spatial calibration is defined with the daily rain gauge network and is kept constant in time.

cific discharge, watershed area, peak times) are listed in Table 2.

The spatial distribution of the peak discharges is not surprising and corresponds quite well to the distribution of the total rainfall amounts. Such totals only partly reflect the rain rates, which are of course influential on the peak discharges. The contributions of most of the tributaries of the Gard and Vidourle Rivers appear very high. Peak specific discharges of more than $5 \mathrm{~m}^{3}$ $\mathrm{s}^{-1} \mathrm{~km}^{-2}$ (and $10 \mathrm{~m}^{3} \mathrm{~s}^{-1} \mathrm{~km}^{-2}$, respectively) are observed on almost the whole Gard and Vidourle watershed areas (over one third to one half of these areas, respectively). Note that the 10 -yr return period discharge is in the range of $2-3 \mathrm{~m}^{3} \mathrm{~s}^{-1} \mathrm{~km}^{-2}$ for such watershed areas in this region. The peak discharges of some tributaries located in the vicinity of the $600-\mathrm{mm}$ rain core have exceeded $20 \mathrm{~m}^{3} \mathrm{~s}^{-1} \mathrm{~km}^{-2}$ (e.g., watersheds $10,11,12)$. These specific discharges are among the highest ever reported for this range of watershed sizes (Costa 1987; Pardé 1961). The spatial extension of the heavy rainfall event explains the very high total discharge of both the Gard and the Vidourle Rivers. The peak discharge of the Gard River is estimated to about $6000 \mathrm{~m}^{3} \mathrm{~s}^{-1}$ at the entrance of the Gard gorges for a watershed area of $1700 \mathrm{~km}^{2}$ (i.e., a specific discharge of about $3.5 \mathrm{~m}^{3} \mathrm{~s}^{-1} \mathrm{~km}^{-2}$ ). Respective figures for the Vidourle watershed are $2000 \mathrm{~m}^{3} \mathrm{~s}^{-1}, 800 \mathrm{~km}^{2}$, and $2.5 \mathrm{~m}^{3} \mathrm{~s}^{-1} \mathrm{~km}^{-2}$. 


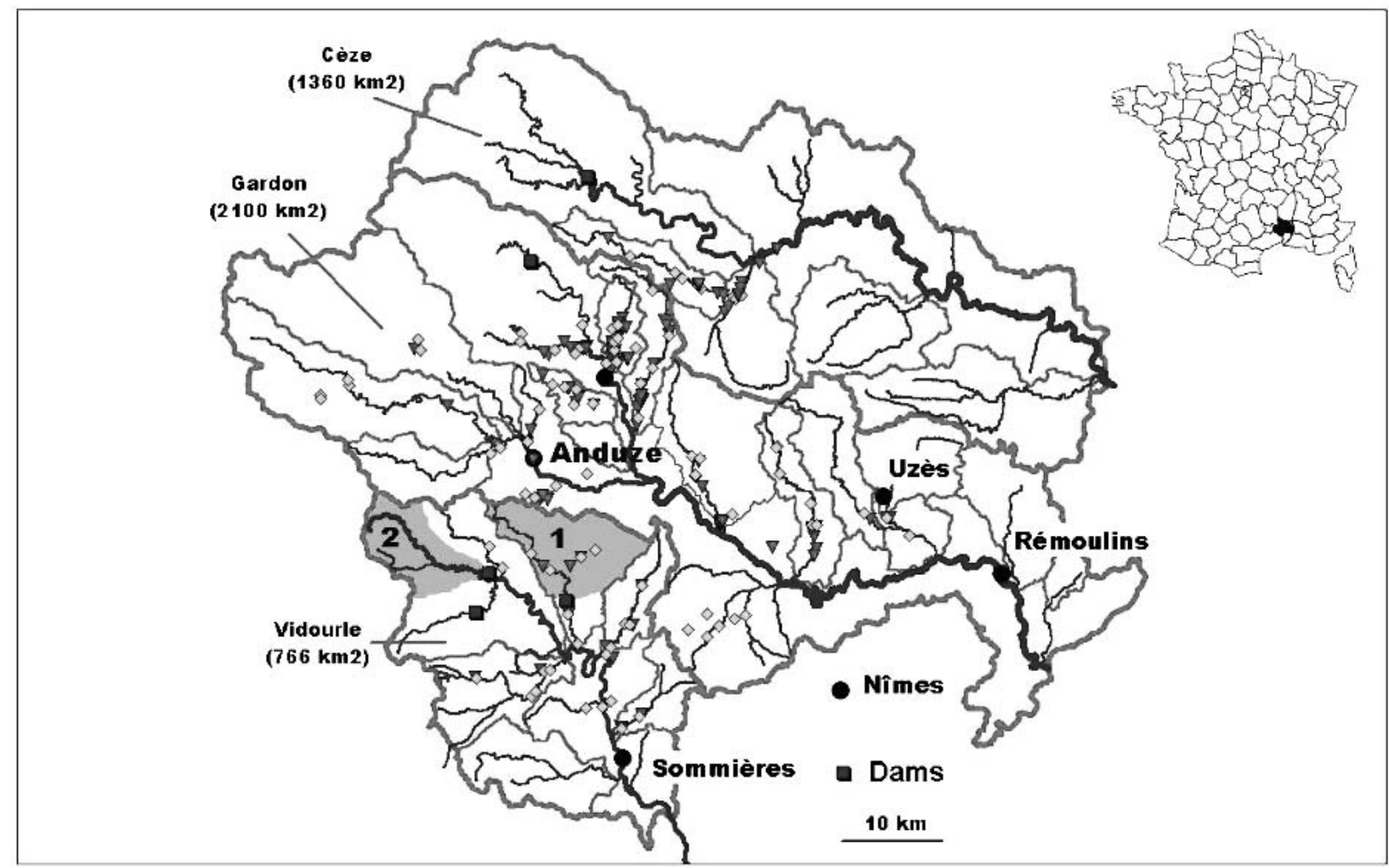

FIG. 10. Location of the Vidourle, Gard, and Cèze River watersheds and of the data during the postevent investigation: witness accounts (triangles) and peak discharge estimates (diamonds). The location of the Crieulon and upper Vidourle watersheds discussed in section $5 \mathrm{~b}$ are also shown (gray shaded areas 1 and 2, respectively). The geographical domain corresponds to the light gray box in Fig. 1.

In terms of dynamics, it is interesting to relate the reported peak times to the rain event space-time analysis presented in section $4 \mathrm{~b}$. The downstream tributaries of the Vidourle River clearly responded early to the rainfall that occurred during phase 1: between 1500 (e.g., watershed 1) and 2100 UTC (e.g., watersheds 2 and 6) on 8 September 2002. The response of the downstream tributaries of the Gard River to the phase 1 rain is consistently estimated to have occurred later (at 2200 UTC for watersheds 14 to 16) for the left bank tributaries. In the southern part of the phase 2 rain core (watersheds 4 and 12), the first peak occurred at about 2300 UTC. In the northern part, due to the proximity of the phase 2 and phase 3 rain peaks (watersheds 7, 10, and 11), only one discharge peak, occurring between 0400 and 0600 UTC, was reported by the witnesses. A similar observation was made for the mountainous upstream Cévennes watersheds 8, 9, and 17. The phase 3 rainfall consistently produced the second discharge peak between 0500 and 0800 UTC in the upstream tributaries and between 0900 and 1100 UTC in the downstream tributaries on 9 September 2002. In the Gard plains, there is evidence of concomitancy between the Gard flood and the secondary flash floods occurring on the downstream Gard tributaries (watersheds 14, 15, and 16) during the cold front passage, due to the delayed contribution of the upstream tributaries. This fact probably increased the hydrological impact of the rain event.

The spatial-temporal analysis of the postevent investigation data just presented leads to expected results: the headwater tributaries reacted with a slight delay to the rainfall bursts observed during the three phases of the rain event and the highest specific discharges occurred where the rain event was the most intense. A complex response, to be analyzed in detail in future work, is likely in the Gard plains during the morning of 9 September 2002 as a result of the convolution of the spatial-temporal structure of the rain event with the geomorphologic characteristics of the watersheds.

\section{b. Typical hydrological behaviors}

The hydrological model proposed by Gaume et al. (2004) was implemented for a preliminary analysis of the postevent investigation dataset. To briefly recall the main characteristics of this model: 1) the watershed is represented as a cascade of river reaches having a rectangular cross section, connected to two rectangular slopes; 2) the floods are assumed to be essentially produced by surface or subsurface runoff water; 3) the Soil 


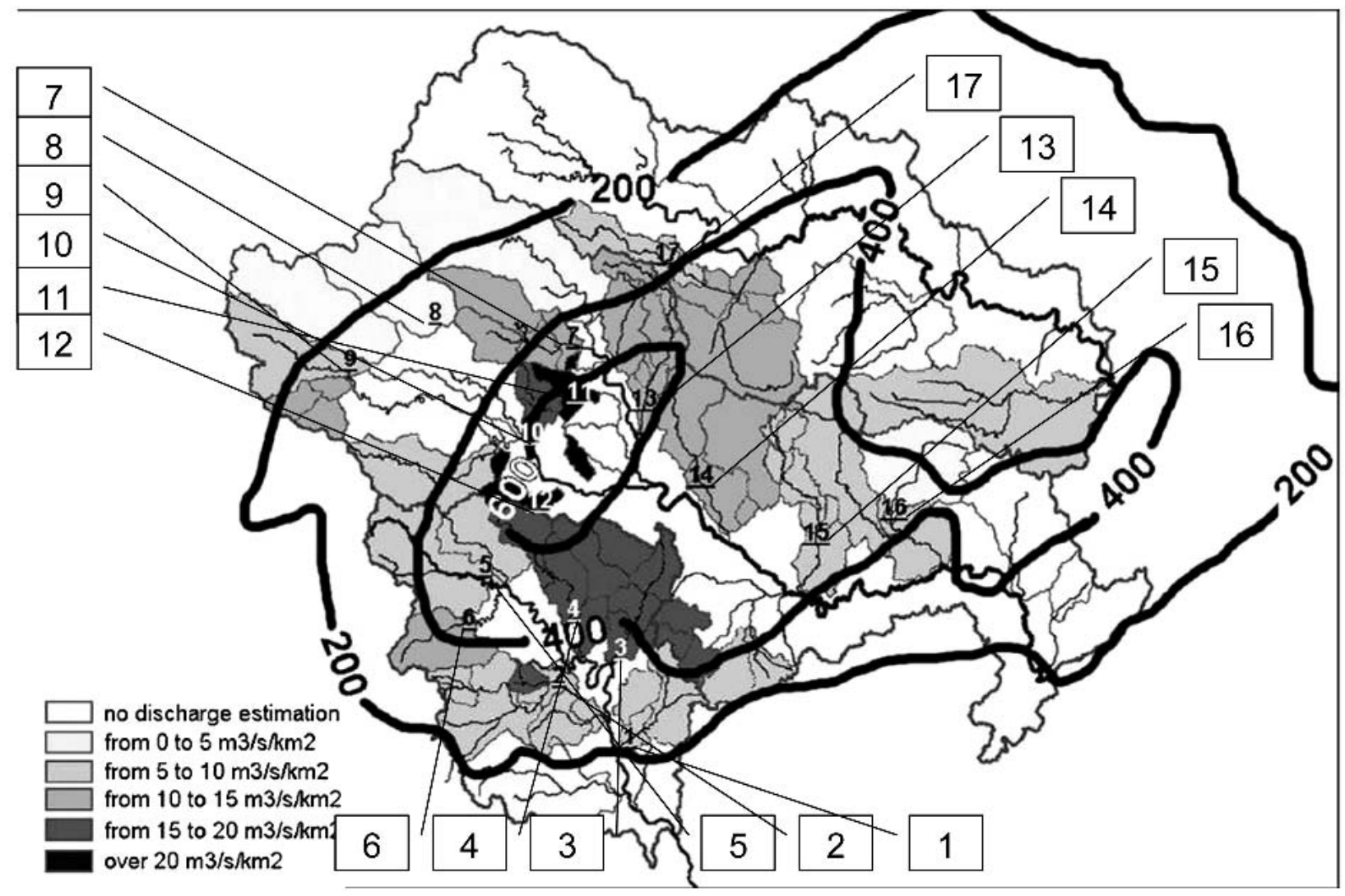

FIG. 11. Estimated peak specific discharges of the upstream tributaries of the Vidourle, Gard, and Cèze Rivers. The 200-, 400-, and $600-\mathrm{mm}$ rain isolines are superimposed on the terrain data. The numbers from 1 to 17 refer to the watershed data listed in Table 2 . The geographical domain corresponds to the light gray box in Fig. 1.

Conservation Service (SCS) model is used, because of its simplicity, to evaluate the mean runoff coefficient on each subwatershed and its evolution during the rain event; and 4) the kinematic wave model is used to route the flood flows through the watershed.

The evolution of the runoff coefficient value during the event is derived from the basic SCS equations:

$$
Q_{t}=\frac{\left(P_{t}-0.2 S\right)^{2}}{\left(P_{t}+0.8 S\right)},
$$

where $Q_{t}$ and $P_{t}$ are the accumulated runoff and rainfall amounts (expressed in millimeters), respectively, from the beginning of the event up to time $t$. The unique parameter of the model is the watershed retention capacity $S(\mathrm{~mm})$, associated with the particular event, which is related to the well-known SCS "curve number" by

$$
S=25.4\left(\frac{1000}{\mathrm{CN}}-10\right) .
$$

The $\mathrm{CN}$ parameter takes a value in the range from 0 (infinite retention capacity, null runoff) to 100 (no retention capacity, runoff equal to $100 \%$ ). For $P_{t}>0.2 S$, the instantaneous runoff coefficient $C_{t}$ depends on the total rainfall amount from the beginning of the event, and not on the rainfall intensity:

$$
C_{t}=2 \frac{\left(P_{t}-0.2 S\right)}{\left(P_{t}+0.8 S\right)}-\left[\frac{\left(P_{t}-0.2 S\right)}{\left(P_{t}+0.8 S\right)}\right]^{2} .
$$

The model is actually not calibrated; instead, several simulations are performed for several $\mathrm{CN}$ values in the range from 50 to 100 . Concerning the flow routing model, the number of reaches depends on the morphological complexity of the watershed rather than on its area. The width and Manning coefficients of each river reach correspond to those evaluated during the field investigation. The Manning coefficent of the slopes is empirically set to 0.1 when the area was larger than 1 $\mathrm{km}^{2}$ and 0.2 in other cases. The comparison of the simulated hyetographs with the sparse available discharge data (only peak discharges and peak times were available at most locations) give two types of information concerning the rainfall-runoff process through the watershed: 1) it provides an evaluation of the mean runoff coefficient at various moments during the event, and 2) if the match between the model results and the available data is correct, then the $\mathrm{CN}$ value allows an esti- 
TABLE 2. Summary of the postevent hydrological investigation in terms of peak discharge and time of the reported discharge peaks. The numbers in the first column refer to the watershed locations shown in Fig. 11.

\begin{tabular}{|c|c|c|c|c|c|c|}
\hline No. & $\begin{array}{l}\text { Watershed name and } \\
\text { exutory location }\end{array}$ & $\begin{array}{l}\text { Watershed } \\
\text { area }\left(\mathrm{km}^{2}\right)\end{array}$ & $\begin{array}{l}\text { Peak discharge } \\
\qquad\left(\mathrm{m}^{3} \mathrm{~s}^{-1}\right)\end{array}$ & $\begin{array}{c}\text { Peak specific } \\
\text { discharge } \\
\left(\mathrm{m}^{3} \mathrm{~s}^{-1} \mathrm{~km}^{-2}\right)\end{array}$ & $\begin{array}{c}\text { Time of first } \\
\text { peak (UTC, date) }\end{array}$ & $\begin{array}{c}\text { Time of second } \\
\text { peak (UTC, date) }\end{array}$ \\
\hline 1 & Aigalade, Pondre & 42 & 250 & 6 & 1500,8 Sep & 1100,9 Sep \\
\hline 2 & Brestalou, Brouzet-les-Quissac & 88 & 500 & 5.5 & 2100,8 Sep & 0800,9 Sep \\
\hline 3 & Courme, Montmirat & 38 & 650 & 17 & 1700,8 Sep & 1000,9 Sep \\
\hline 4 & Crieulon, Ia Rouvière & 95 & 1400 & 15 & 2300,8 Sep & 0800,9 Sep \\
\hline 5 & Vidourle, Conqueyrac & 83 & 600 & 7 & 0000,9 Sep & 0600,9 Sep \\
\hline 6 & Rieumassel, Ceyrac & 45 & 500 & 11 & 2100,8 Sep & 0900, 9 Sep \\
\hline 7 & Galeizon & 85 & 1200 & 14 & 0600,9 Sep & \\
\hline 8 & Gardon de Mialet, Saint Etienne & 84 & 400 & 5 & 0400,9 Sep & \\
\hline 9 & Gardon de Saint Jean, Saumane & 67 & 500 & 7.5 & 0600,9 Sep & \\
\hline 10 & Amous, Générargues & 21 & 400 & 19 & 0400,9 Sep & \\
\hline 11 & Alzon, Saint Jean du Pin & 15 & 450 & 30 & 0500,9 Sep & \\
\hline 12 & Ourne, Tornac & 11 & 300 & 27 & 2300,8 Sep & 0600, 9 Sep \\
\hline 13 & Avène, Saint Hilaire de Brethmas & 57 & 600 & 10.5 & 0300,9 Sep & 0500,9 Sep \\
\hline 14 & Droude, Brignon & 99 & 1200 & 12 & 2200,8 Sep & 0900, 9 Sep \\
\hline 15 & Bourdic, Bourdic & 39 & 500 & 13 & 2200,8 Sep & 1000,9 Sep \\
\hline 16 & Alzon, Uzès & 76 & 250 & 3 & 2200,8 Sep & 1000,9 Sep \\
\hline 17 & Auzonnet, Les Mages & 46 & 450 & 10 & 0600,9 Sep & \\
\hline
\end{tabular}

mation of the watershed retention capacity for this event.

The preliminary analysis reveals different types of hydrological behaviors among the available data. Two examples are presented here for the watersheds of the Crieulon stream $\left(93 \mathrm{~km}^{2}\right)$ and the upper Vidourle River $\left(86 \mathrm{~km}^{2}\right)$ - see Fig. 10 for location. In the case of these two watersheds closed by the dams at La Rouvière and Conqueyrac, respectively, complete hydrographs could be reconstructed with a relatively good confidence from hydraulic data of the dam works. Table 3 presents the volumetric balance that could be established for these two watersheds considering the areal rainfall estimated with the spatially calibrated data of the two weather radar systems. Note that the areal rainfall is significantly different for the two watersheds (about 530 and $360 \mathrm{~mm}$, respectively) and is known with an uncertainty of about $10 \%$ in both cases. The runoff deficit can be estimated to about 95 and $130 \mathrm{~mm}$ for the Crieulon and Vidourle watersheds, respectively. Such deficit values appear relatively low if compared to other studies of recent flash floods (Gaume et al. 2003, 2004). Figure 12 shows the results of the hydrological model implementation. The hydrological model appears to be quite well suited to the Crieulon watershed in terms of synchronization and amplitude of the different peaks. The curve number optimal to simulate the beginning of the hydrograph $(\mathrm{CN}$ of about 70 , that is a retention capacity of about $110 \mathrm{~mm}$ ) is very consistent with the deficit estimated with the measured hyetographs and hydrograph. The simulations indicate that the runoff coefficient was certainly very close to $100 \%$ during the second half of the flood. The hydrological behavior observed for the Crieulon stream is typical of watersheds mainly on marls and nonkarstified limestone. For the Vidourle watershed, located in a karstic area, the hydrological simulations are much less satisfactory: the watershed clearly has some important rainfall water retention capacities during the flood. Moreover, a relatively high discharge, not simulated by the rainfallrunoff model, remains after the rain event has ceased. This indicates that a part of the stored rainwater (about one third in the presented case) is returned during the days following the flood event. This behavior attributed to the karstic nature of the watershed geology, seems to occur also for steep watersheds on schist often supposed to be impervious.

\section{Discussion and future work}

The 8-9 September 2002 catastrophic rain event occurred in a meteorological context propitious to heavy precipitation in southeastern France. A third-level (out

TABLE 3. Volumetric balance for the Crieulon and Vidourle Rivers at the Barrage de la Rouvière $\left(93 \mathrm{~km}^{2}\right)$ and the Barrage de Conqueyrac $\left(86 \mathrm{~km}^{2}\right)$ dams.

\begin{tabular}{llccr}
\hline \hline Watershed & \multicolumn{1}{c}{ Rainfall estimation } & Areal rainfall $(\mathrm{mm})$ & Runoff $(\mathrm{mm})$ & Deficit $(\mathrm{mm})$ \\
\hline Crieulon & Spatially calibrated Nîmes radar & 514 & 439 & 75 \\
& Spatially calibrated Bollène radar & 555 & 439 & 116 \\
Vidourle & Spatially calibrated Nîmes radar & 384 & 232 & 152 \\
& Spatially calibrated Bollène radar & 340 & 232 & 108 \\
\hline
\end{tabular}




\section{a) Crieulon hydrographs}

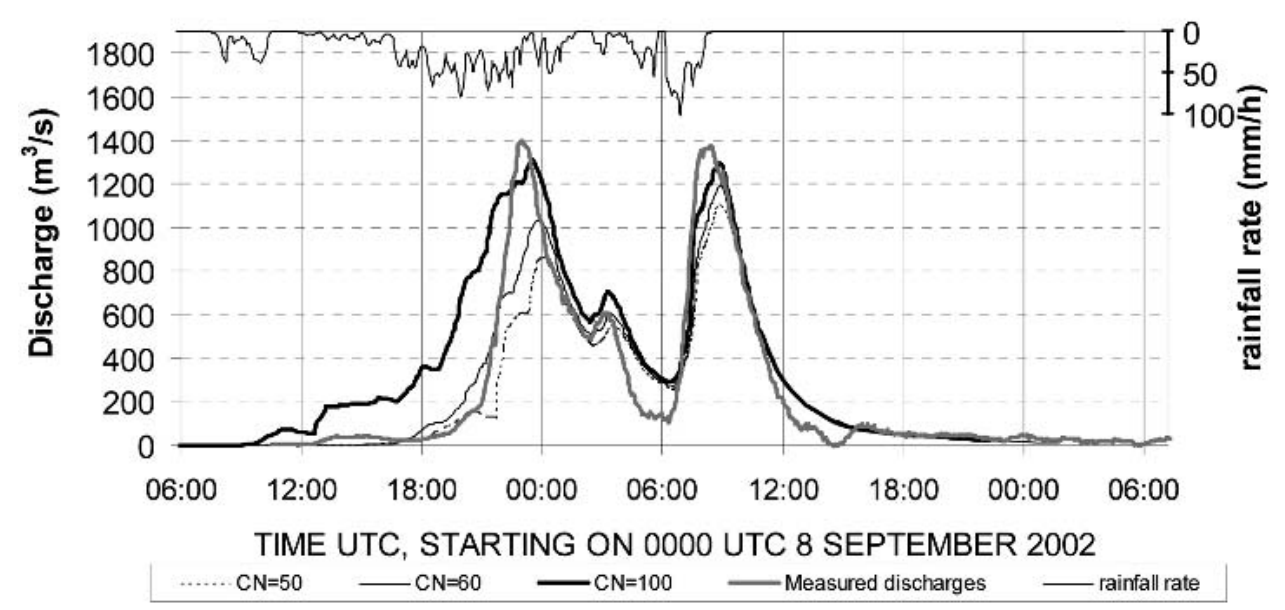

\section{b) Vidourle hydrographs}

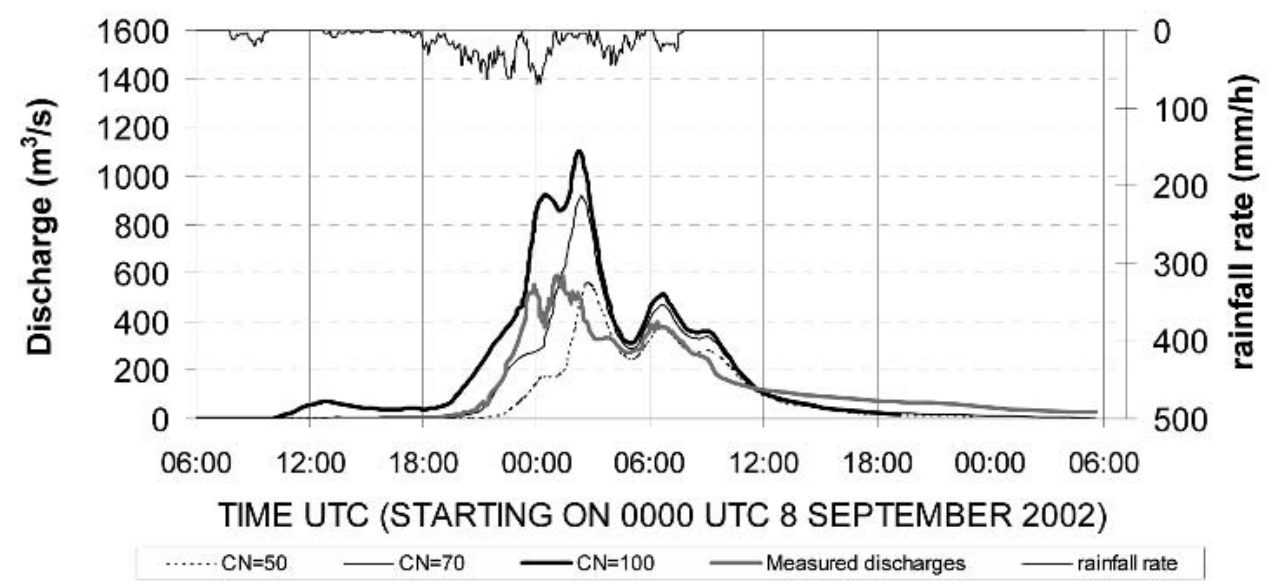

FIG. 12. Measured (thick gray line) and simulated hydrographs for various $\mathrm{CN}$ parameter values for (a) the Crieulon and (b) the upstream Vidourle watersheds. The corresponding 5-min areal rainfall, derived from the spatially calibrated Bollène radar data, is displayed in the upper part of the graphs.

of four) warning bulletin was issued by Météo-France at 0353 UTC 8 September 2002, prior to the event, indicating possible rain amounts in the range of 30-50 $\mathrm{mm}$ in the Gard plains with local maxima of $70-150$ $\mathrm{mm}$. This warning level was maintained, and the forecasts updated, during the following bulletins of the day of 8 September 2002. The fourth-level warning bulletin was issued at 2327 UTC 8 September 2002, prior to the passage of the cold front over the region, which provided useful information regarding the expected rain intensification while the situation was already extremely difficult in the region. Note that, as a result of both coarse grid resolution and parameterized (rather than explicit) representation of convection, the current operational meteorological models significantly under- predicted the amount of precipitation and incorrectly predicted its position by about $100 \mathrm{~km}$. The mesoscale observations during the event, and notably the satellite and radar observation of the typical $\mathrm{V}$ shape of the stationary MCS, were certainly critical in the real-time management of the crisis.

The improvement of quantitative precipitation forecasts is therefore a major objective of the meteorological teams within the OHM-CV. The high-resolution, nonhydrostatic, Meso-NH model (Lafore et al. 1998) is used at Centre National de Recherche Météorologique (CNRM) to prepare the future operational model generation in the framework of the Météo-France AROME project. Simulations of the 8-9 September 2002 rain event indicate that, compared to the presently 
operational ARPEGE model, the Meso-NH code, with two nested domains having resolutions of 10 and 2.5 $\mathrm{km}$, respectively, improves by a factor of about 2 the predicted 24-h precipitation amounts when the operational ARPEGE analyses are used as initial conditions by both models. However, the forecast location of the rain is still shifted to the north in such simulations. The implementation of the initialization procedure proposed by Ducrocq et al. (2000), based on ground-based mesoscale observations, improves the prediction of the MCS position and thus offers the opportunity to start studying the mechanisms responsible for the anchoring and the stationnarity of the MCS.

In parallel, the tremendous rainfall productivity of Mediterranean precipitation events is a subject of reflection for the Laboratoire de Météorologie Physique (LaMP) team who uses the Clark model (Clark et al. 1994; Wobrock et al. 2003) for testing the sensitivity of the OHM-CV cases, and notably the 8-9 September 2002 rain event, to the microphysical schemes. Another line of research for the meteorological teams is the determination of meteorological precursors that are critically needed to improve the early diagnosis of the potential for extreme weather. In this field, the study of potential vorticity anomalies, already initiated for the Mediterranean heavy rainfall events within the Mesoscale Alpine Programme (Bougeault et al. 1998, 2001), are being developed.

As a complement to high-resolution meteorological modelling, an analog sorting method, initially proposed by Duband (1981), is being refined (Guilbaud 1997; Bontron 2004). Using the analogy between the current and past situations, this method allows probabilistic quantitative precipitation forecasts to be issued in realtime over a set of Mediterranean and Alpine mediumsized (500-1000 $\mathrm{km}^{2}$ ) watersheds. Recent work allowed testing of new analogy criteria and new prognostic variables (Obled et al. 2003), thanks to the availability of the National Centers for Environmental PredictionNational Center for Atmospheric Research reanalyses. A real-time prototype has raised the alarm for the 8-9 September 2002 rain event more than $24 \mathrm{~h}$ in advance.

The development of weather observation techniques is also an important goal for the OHM-CV. The use of weather radars is specifically addressed by means of cooperative studies between Météo-France and several research teams. The Bollène 2002 experiment has been carried out with the aim of developing radar processing techniques based on volumetric radar scanning strategies to generate $2 \mathrm{D}$ and $3 \mathrm{D}$ rain products for hydrological and meteorological applications. These procedures, essential to improve the "hydrologic visibility" (Pellarin et al. 2002) of the weather radars in these mountainous regions, are hoped to be generalized to all the radars of the ARAMIS Arc Méditerranéen network in the future. Note that the Bollène 2002 experimental dataset includes the 8-9 September 2002 case thus offering the opportunity to refine, with a 13 eleva- tion-angle scanning strategy, the radar rainfall estimates compared to the results presented in the present paper. Besides the weather radar program the OHM$\mathrm{CV}$ promotes the development, rather than the ongoing decline, of the existing rain gauge networks, notably for the subdaily time steps. Furthermore, the use of GPS sensors for atmospheric water vapor estimation is the subject of ongoing experiments in the CévennesVivarais window. The objective is an improved assessment of the water vapor inflow into the region of interest, which certainly represents a crucial point for improving the effectiveness of precipitation forecasting techniques.

Concerning the hydrological impact of such intense rain events, several research actions are also undertaken. The 8-9 September 2002 postevent investigation dataset is the subject of a detailed study to confirm the influence of both the space-time structure of the rain event and the geomorphological factors on the subsequent hydrologic response of the watersheds. A 2D hydraulic model, using the estimated discharge time series as boundary conditions, will be implemented in a final step for simulating the flood propagation and the overflows in the hydrographic network. The procedures used to collect and analyze the postevent investigation data will be progressively standardized and refined with future case studies of major events that are foreseen to occur in the region. A better understanding of the hydrological processes at the hillslope scale also requires detailed and long-lasting instrumentation that has been in place for years for several very small granitic watersheds in the Mount Lozère area (Cosandey 1994; Martin et al. 2003). A similar approach is starting for small watersheds on schists of the Gardon d'Anduze River (Ayral et al. 2003). The development of remote sensing techniques for discharge measurement during floods (Creutin et al. 2003) is also particularly important for both operational and research application: an existing video-imagery-based prototype enabling the real-time monitoring of both water levels and surface flow velocities will be soon deployed in the Cévennes-Vivarais watersheds. Besides such observation activities, a continuing effort is dedicated to rainfall-runoff modeling with the dual objectives (i) of adapting the hydrological model structures to the distributed information that is now available on rainfall and land properties (e.g., Saulnier et al. 1997; Pellarin et al. 2002; Ayral et al. 2005); and (ii) of assessing the impact of the various sources of uncertainty (measurement error, model structure, parameterization) to produce confidence intervals for the predicted hydrographs (e.g., Zin 2002). The problem of transferring and estimating the parameterization of hydrological models in ungauged basins is especially acute in this context and this subject will deserve specific attention in the future. Finally, a longterm objective is to develop a coupled modelling approach by using high-resolution meteorological models 
together with distributed hydrological models in order to obtain an integrated forecast of the rainfall and of the subsequent flash floods.

Concerning the historical approach, a specific research program called InodHis-LR will focus in the next two years (2004-2005) on a regional analysis of extreme rainfall and flood events in the LanguedocRoussillon region, which overlaps the CévennesVivarais area. Historical data on two large watersheds (the Hérault and Gard Rivers) and five subcatchments of the Aude River will be collected over a period of about two centuries to complement the Ardèche case study (Naulet et al. 2004). This will allow refinement of flood frequency analysis at the regional scale and, in particular, to assess the 8-9 September 2002 catastrophic event from a climatological perspective.

\section{Conclusions}

Inline with previously published flash-flood monographs, the present paper was aimed at documenting the 8-9 September 2002 catastrophic rain event that occurred in the Gard region, France. A description of the synoptic meteorological situation was first given, which showed that all the ingredients required for heavy precipitation in the region were present with, although, no particular precursor suggesting the imminence of such an extreme event. Radar and rain gauge observations then allowed an assessment of the magnitude of the rain event which is particularly remarkable by its spatial extension with rain amounts greater than $200 \mathrm{~mm}$ over $5500 \mathrm{~km}^{2}$ in $24 \mathrm{~h}$. The maximum values of $600-700 \mathrm{~mm}$ observed locally are among the highest daily records in the region. From a dynamical point of view, the rain event is characterized by three phases corresponding to a first localization of the MCS over the Gard plains, then to a displacement of the MCS toward the Cévennes mountain ridge before the passage of the cold front, which swept the convective activity out of the region. Locally, the MCS produced rain amounts of typically 200-300 $\mathrm{mm}$ in $6 \mathrm{~h}$; the cold front produced additional rain amounts of typically $100 \mathrm{~mm}$. The preliminary results of the postevent hydrological investigation show that the hydrologic response of the upstream watersheds (with sizes in the range of 10-100 $\mathrm{km}^{2}$ ) of the Gard and Vidourle Rivers is consistent with the marked space-time structure of the rain event. Peak specific discharges were very high over most of the affected areas $\left(5-10 \mathrm{~m}^{3} \mathrm{~s}^{-1} \mathrm{~km}^{-2}\right)$ and reached locally extraordinary values of more than $20 \mathrm{~m}^{3} \mathrm{~s}^{-1} \mathrm{~km}^{-2}$. A preliminary analysis indicates contrasting hydrological behaviors that seem to be related to geomorphological factors, notably the influence of karst in part of the region. This extraordinary rain event is the subject of several ongoing research actions performed within the Cévennes-Vivarais Mediterranean Hydrometeorological Observatory. Due to the amount and the high quality of the collected information, it is planned to make the 8-9 September 2002 OHM-CV datasets available to the international scientific community by the end of 2004 .

Acknowledgments. The comments of the three anonymous reviewers were very helpful in improving the manuscript. The OHM-CV initiative has received in the past four years support from the national research programmes PATOM and ECCO/PNRH (INSU/ CNRS), the ACI "Risques Naturels" (French Ministry of Research), Météo-France, the programme "Risque Inondation 2" of the French Ministry of Ecology and Sustainable Development, the "Observatoire des Sciences de l'Univers de Grenoble," and recently from the "Institut National des Sciences de l'Univers" and the "Fond National de la Science" within the programme "Observatoires de Recherche en Environnement" (ORE).

\section{REFERENCES}

Anquetin, S., F. Miniscloux, J. D. Creutin, and S. Cosma, 2003 Numerical simulation of orographic rain. J. Geophys. Res., 108, 8386, doi:10.1029/2002JD001593.

Ayral, P. A., J. F. Desprats, F. Bressand, D. Pinel, S. Sauvagnargues-Lesage, C. King, and N. Dorfliger, 2003: Intégration de la variabilité spatiale de l'infiltration des sols dans le modèle de prévision des crues opérationnels ALHTAÏR: Zone test du bassin versant du Gardon d'Anduze (Integration of the soil infiltration spatial variability into the ALTHAIR operational flood forecasting model: The Gardon d'Anduze test area). Rev. Soc. Fr. Photogramm. Télédéct., 172, 22-30.

— S. Sauvagnargues-Lesage, F. Bressand, and S. Gay, 2005: Forecasting flash-floods with an operational model: Application in the south-east of France (Gard). Nat. Hazards, in press.

Benito, G., and Coauthors, 2004: Use of systematic, paleoflood and historical data for the improvement of flood risk estimation: Review of scientific methods. Nat. Hazards, 31, 623-643.

Berne, A., G. Delrieu, H. Andrieu, and J. D. Creutin, 2004: Influence of the vertical profile of reflectivity on radarestimated rain rates at short time steps. J. Hydrometeor., 5, 296-310.

Bois, P., C. Obled, M. F. De Saintignon, and H. Mailloux, 1997: Atlas Expérimental des Risques de Pluies Intenses: CévennesVivarais (Experimental Atlas of Intense Rainfall in the Cévennes-Vivarais Region). LTHE-LAMA, Pôle Grenoblois d'Etude et de Recherche pour la Prévention des Risques Naturels, EDF-DTG, 19 pp.

Bontron, G., 2004: Prévision quantitative des précipitations: Adaptation probabiliste par recherche d'analogues-Utilisation des réanalyses NCEP/NCAR et application aux précipitations du sud-est de la France (Quantitative precipitation forecasting: Probabilistic adaptation through analog sortingUtilization of the NCEP/NCAR re-analyses and application to southeastern France rain events). Ph.D. thesis, National Polytechnical Institute of Grenoble (INPG), 262 pp.

Bougeault, P., P. Binder, and J. Kuettner, 1998: Mesoscale Alpine Programme science plan. MAP Project Office, Meteo Swiss, Zurich, Switzerland, $64 \mathrm{pp}$.

—, and Coauthors, 2001: The MAP special observing period. Bull. Amer. Meteor. Soc., 82, 433-462.

Clark, T. L., W. D. Hall, and R. M. Banta, 1994: Two- and threedimensional simulations of the 9 January 1989 severe Boulder windstorm: Comparison with observation. J. Atmos. Sci., 51, 2317-2342. 
Cosandey, C., 1994: Formation des crues cévenoles dans les basins élémentaires du Mont Lozère (Genesis of the Cévennes flash floods over small watersheds of the Mount Lozère, France). Rev. Sci. Eau, 7, 377-393.

Costa, J. E., 1987: Hydraulics and basin morphometry of the largest flash floods in the coterminous United States. J. Hydrol., 93, 313-338.

Creutin, J. D., and C. Obled, 1982: Objective analysis and mapping techniques for rainfall fields: An objective comparison. Water Resour. Res., 18, 413-431.

—, M. Muste, A. A. Bradley, S. C. Kim, and A. Kruger, 2003: River gauging using PIV techniques-A proof of concept experiment on the lowa River. J. Hydrol., 277, 182-196.

Duband, D., 1981: Prévision spatiale des hauteurs de précipitations journalières (Spatial forecasting of daily precipitation amounts). Houille Blanche, 7-8, 497-511.

Ducrocq, V., J. P. Lafore, J. L. Redelsperger, and F. Orain, 2000: Initialisation of a fine scale model for convective system prediction: A case study. Quart. J. Roy. Meteor. Soc., 126, 30413066.

— D. Ricard, J. P. Lafore, and F. Orain, 2002: Storm-scale numerical rainfall prediction for five precipitating events over France-On the importance of the initial humidity field. Wea. Forecasting, 17, 1236-1256.

Gaume, E., M. Livet, and M. Desbordes, 2003: Study of the hydrological processes during the Avène River extraordinary flood (south of France): 6-7 October 1997. Phys. Chem. Earth, 28, 263-267.

$\longrightarrow,-,-$, and J.-P. Villeneuve, 2004: Hydrological analysis of the River Aude flash-flood on 12 and 13 November 1999. J. Hydrol., 286, 135-154.

Guilbaud, S., 1997: Prévision quantitative des précipitations journalières par une méthode statistico-dynamique de recherche d'analogues (Daily quantitative precipitation forecasting using an analog sorting method). Ph.D. thesis, National Polytechnical Institute of Grenoble, $258 \mathrm{pp}$.

Huet, P., X. Martin, J. L. Prime, P. Foin, C. Laurain, and P. Cannard, 2003: Retour d'expérience des crues de Septembre 2002 dans les départements du Gard, de l'Hérault, du Vaucluse, des Bouches du Rhône, de l'Ardèche et de la Drome (Post-flood investigation of the 8-9 September 2002 flood in the Gard, Hérault, Vaucluse, Bouches-du-Rhône, Ardèche, and Drome departments). Rapport de l'Inspection Générale de l'Environnement, Ministère de l'Ecologie et du Développement Durable, République Française, 133 pp. [Available online at http://www.ecologie.gouv.fr/article.php3?id_ article $=1011$.]

Jacq, V., 1994: Inventaire des situations à précipitations diluviennes sur les régions Languedoc-Roussillon, PACA et Corse, période 1958-1994. (Inventory of extreme precipitation events in the Languedoc-Roussillon, Provence Côte d'Azur and Corse regions in the period 1958-1994). Phénomènes remarquables, No. 3, Météo France, SCEM, 190 pp.

Kieffer, A., and P. Bois, 1997: Variabilité des caractéristiques statistiques des pluies extrêmes dans les Alpes françaises (Variability of extreme rainfall statistics in the French Alps). Rev. Sci. Eau, 10, 199-216.

Lafore, J. P., and Coauthors, 1998: The Meso-NH atmospheric simulation system. Part 1: Adiabatic formulation and control simulations. Ann. Geophys., 16, 90-109.

Lebel, T., G. Bastin, C. Obled, and J. D. Creutin, 1987: On the accuracy of areal rainfall estimation: A case study. Water Resour. Res., 23, 2123-2134.
Martin, C., J. F. Didon-Lescot, and C. Cosandey, 2003: Le fonctionnement hydrologique des petits bassins versants granitiques du Mont-Lozère: Influence du couvert végétal sur les crues et les étiages (Hydrological behavior of the small granitic watersheds of the Mount Lozère, France: Influence of land cover on floods and droughts). Etud. Géogr. Phys., 30, $3-25$.

Miniscloux, F., J. D. Creutin, and S. Anquetin, 2001: Geostatistical analysis of orographic rainbands. J. Appl. Meteor., 40, $1835-1854$.

Naulet, R., M. Lang, T. Ouarda, D. Coeur, B. Bobbée, A. Recking, and D. Moussay, 2004: Flood frequency analysis on the Ardeche River using French documentary sources from the two last centuries. J. Hydrol., in press.

Neppel, L., 1997: Le risque pluvial en région LanguedocRoussillon: Caractérisation de l'aléa climatique (Flood risk in the Languedoc-Roussillon region: Characterization of the climatic hazard). Ph.D. thesis. University of Montpellier II, 272 pp.

Obled, C., G. Bontron, and R. Garçon, 2003: Quantitative precipitation forecasting - A statistical adaptation of model outputs through an analog sorting approach. J. Atmos. Res., 63, 303-324.

Ogden, F. L., H. O. Sharif, S. U. S. Senarath, J. A. Smith, M. L. Baeck, and J. R. Richardson, 2000: Hydrologic analysis of the Fort Collins, Colorado flash flood of 1997. J. Hydrol., 228, $82-100$.

Pardé, M., 1961: Sur la puissance des crues en diverses parties du monde. Geographica, 8, 293 pp.

Pellarin, T., G. Delrieu, G. M. Saulnier, H. Andrieu, B. Vignal, and J. D. Creutin, 2002: Hydrologic visibility of weather radars operating in mountainous regions: Case study for the Ardèche catchment (France). J. Hydrometeor., 3, 539-555.

Rivrain, J. C., 1998: Les épisodes orageux à précipitations extrêmes dans les régions méditerranéennes du sud de la France (Storm-floods in the Mediterranean region of southern France). Phénomènes remarquables, No. 4, Météo France, SCEM, 93 pp.

Saulnier, G. M., K. Beven, and C. Obled, 1997: Digital elevation analysis for distributed hydrological modelling: Reducing scale dependence in effective hydraulic conductivity values. Water Resour. Res., 33, 2097-2101.

Sheffer, N. A., Y. Enzel, G. Benito, T. Grodek, N. Poart, M. Lang, R. Naulet, and D. Coeur, 2004: Paleofloods and historical floods of the Ardèche River, France. Water Resour. Res., 39, 1376, doi:10.1029/2003WR002468.

Smith, J. A., M. L. Baeck, M. Steiner, and A. J. Miller, 1996: Catastrophic rainfall from an upslope thunderstorm in the central Appalachians: The Rapidan storm of 27 June 1995. Water Resour. Res., 32, 3099-3113.

Walpersdorf, A., E. Calais, J. Haase, L. Eymard, M. Desbois, and H. Vedel, 2001: Atmospheric gradients estimated by GPS compared to a high resolution numerical weather prediction (NWP) model. Phys. Chem. Earth, 26A (3), 147-152.

Wobrock, W., A. F. Flossman, and R. D. Farley, 2003: Comparison of modeled and observed hailstone spectra during a severe storm over the northern Pyrenean foothills. Atmos. Res., 67-68, 685-703.

Zin, I., 2002: Incertitudes et ambiguïté dans la modélisation hydrologique (Uncertainties and ambiguity in hydrological modeling). Ph.D. thesis, National Polytechnical Institute of Grenoble (INPG), 200 pp. 